\title{
LEVEL II SCOUR ANALYSIS FOR BRIDGE 2 (SOMMTH00010002) on TOWN HIGHWAY 1, crossing the RAKE BRANCH DEERFIELD RIVER, SOMERSET, VERMONT
}

Open-File Report 98-535

Prepared in cooperation with

VERMONT AGENCY OF TRANSPORTATION

and

FEDERAL HIGHWAY ADMINISTRATION

U.S. Department of the Interior

U.S. Geological Survey

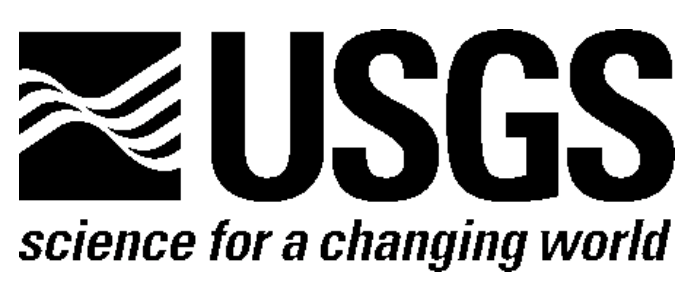




\section{LEVEL II SCOUR ANALYSIS FOR BRIDGE 2 (SOMMTH00010002) on TOWN HIGHWAY 1, crossing the RAKE BRANCH DEERFIELD RIVER, SOMERSET, VERMONT \\ By RONDA L. BURNS}

U.S. Geological Survey Open-File Report 98-535

Prepared in cooperation with

VERMONT AGENCY OF TRANSPORTATION

and

FEDERAL HIGHWAY ADMINISTRATION

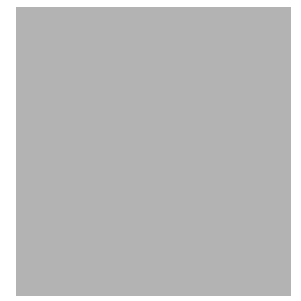




\title{
U.S. DEPARTMENT OF THE INTERIOR BRUCE BABBITT, Secretary
}

\author{
U.S. GEOLOGICAL SURVEY
}

Thomas J. Casadevall, Acting Director

For additional information write to:

District Chief

U.S. Geological Survey 361 Commerce Way

Pembroke, NH 03275-3718
Copies of this report may be purchased from:

U.S. Geological Survey

Branch of Information Services

Open-File Reports Unit

Box 25286

Denver, CO 80225-0286 


\section{CONTENTS}

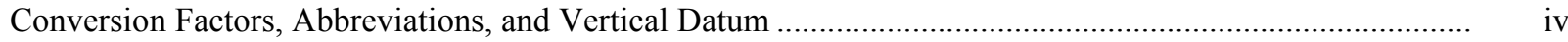

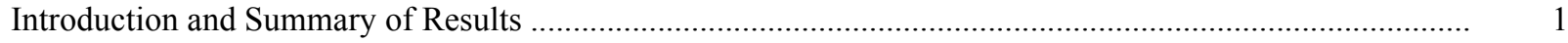

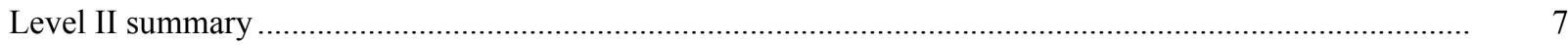

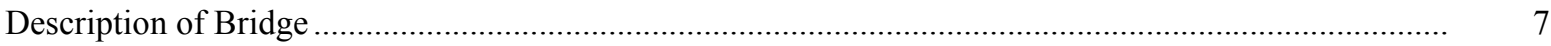

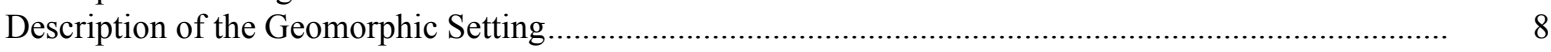

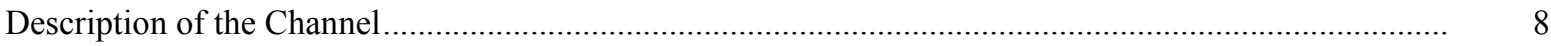

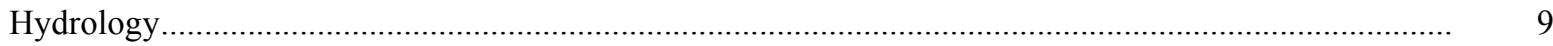

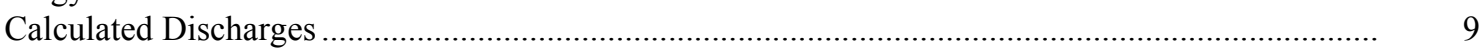

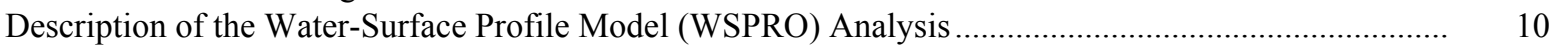

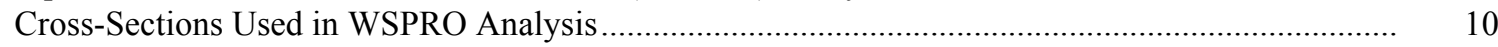

Data and Assumptions Used in WSPRO Model ........................................................................ 11

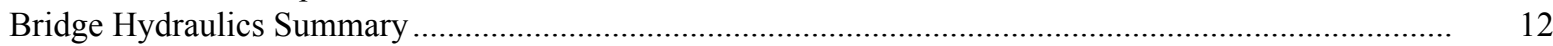

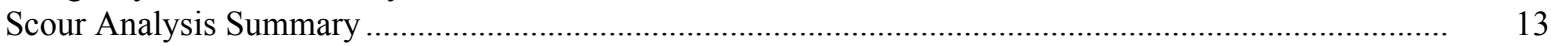

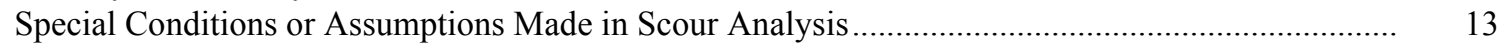

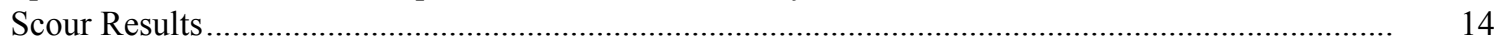

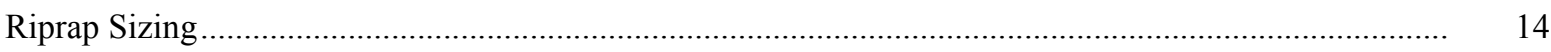

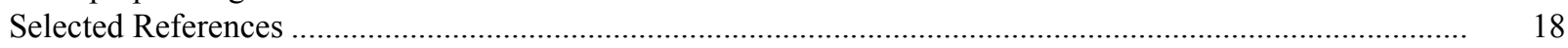

Appendices:

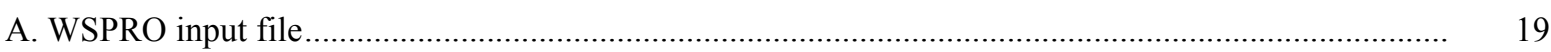

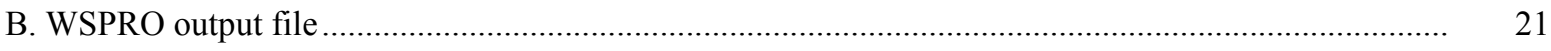

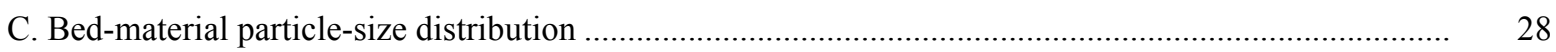

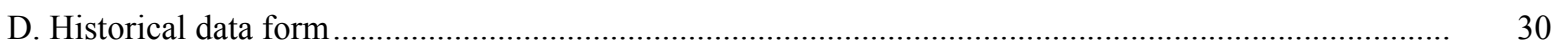

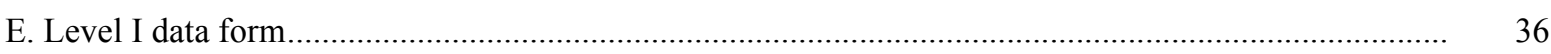

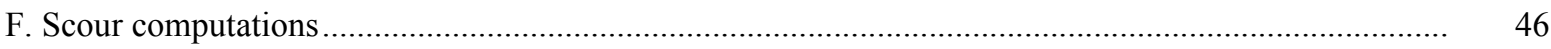

\section{FIGURES}

1. Map showing location of study area on USGS 1:24,000 scale map

2. Map showing location of study area on Vermont Agency of Transportation town highway map

3. Structure SOMMTH00010002 viewed from upstream (August 7, 1996)

4. Downstream channel viewed from structure SOMMTH00010002 (August 7, 1996)............................ 5

5. Upstream channel viewed from structure SOMMTH00010002 (August 7, 1996)..................................

6. Structure SOMMTH00010002 viewed from downstream (August 7, 1996).

7. Water-surface profiles for the 100- and 500-year discharges at structure SOMMTH00010002 on Town Highway 1, crossing the Rake Branch Deerfield River, Somerset, Vermont.

8. Scour elevations for the 100- and 500-year discharges at structure

SOMMTH00010002 on Town Highway 1, crossing the Rake Branch Deerfield River,

Somerset, Vermont.

\section{TABLES}

1. Remaining footing/pile depth at abutments for the 100-year discharge at structure

SOMMTH00010002 on Town Highway 1, crossing the Rake Branch Deerfield River,

Somerset, Vermont.

2. Remaining footing/pile depth at abutments for the 500-year discharge at structure

SOMMTH00010002 on Town Highway 1, crossing the Rake Branch Deerfield River,

Somerset, Vermont 


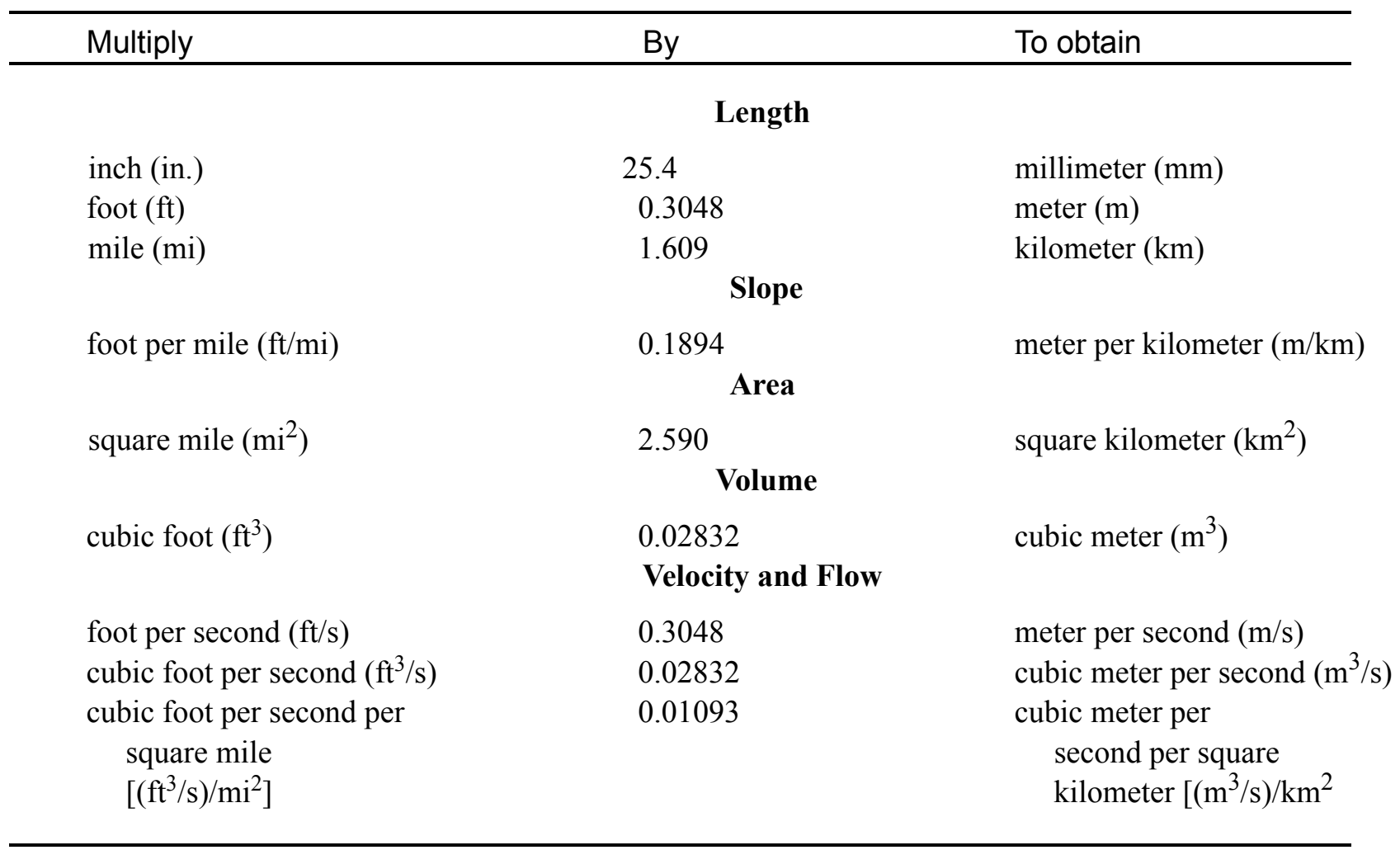

\section{OTHER ABBREVIATIONS}

$\begin{array}{lrlr}\mathrm{BF} & \text { bank full } & \text { LWW } & \text { left wingwall } \\ \mathrm{cfs} & \text { cubic feet per second } & \text { Max } & \text { maximum } \\ \mathrm{D}_{50} & \text { median diameter of bed material } & \text { MC } & \text { main channel } \\ \mathrm{DS} & \text { downstream } & \text { RAB } & \text { right abutment } \\ \mathrm{elev} & \text { elevation } & \text { RABUT } & \text { face of right abutment } \\ \mathrm{f} / \mathrm{p} & \text { flood plain } & \text { RB } & \text { right bank } \\ \mathrm{ft} & \text { square feet } & \text { ROB } & \text { right overbank } \\ \mathrm{ft} / \mathrm{ft} & \text { feet per foot } & \text { RWW } & \text { right wingwall } \\ \mathrm{FEMA} & \text { Federal Emergency Management Agency } & \text { TH } & \text { town highway } \\ \mathrm{FHWA} & \text { Federal Highway Administration } & \text { UB } & \text { under bridge } \\ \mathrm{JCT} & \text { junction } & \text { US } & \text { upstream } \\ \text { LAB } & \text { left abutment } & \text { USGS } & \text { United States Geological Survey } \\ \text { LABUT } & \text { face of left abutment } & \text { VTAOT } & \text { Vermont Agency of Transportation } \\ \text { LB } & \text { left bank } & \text { WSPRO } & \text { water-surface profile model } \\ \text { LOB } & \text { left overbank } & \text { yr } & \text { year }\end{array}$

In this report, the words "right" and "left" refer to directions that would be reported by an observer facing downstream. Sea level: In this report, "sea level" refers to the National Geodetic Vertical Datum of 1929-- a geodetic datum derived from a general adjustment of the first-order level nets of the United States and Canada, formerly called Sea Level Datum of 1929.

In the appendices, the above abbreviations may be combined. For example, USLB would represent upstream left bank. 


\title{
LEVEL II SCOUR ANALYSIS FOR BRIDGE 2 (SOMMTH00010002) ON TOWN HIGHWAY 1, CROSSING THE RAKE BRANCH DEERFIELD RIVER, SOMERSET, VERMONT
}

\author{
By Ronda L. Burns
}

\section{INTRODUCTION AND SUMMARY OF RESULTS}

This report provides the results of a detailed Level II analysis of scour potential at structure SOMMTH00010002 on Town Highway 1 crossing the Rake Branch Deerfield River, Somerset, Vermont (figures 1-8). A Level II study is a basic engineering analysis of the site, including a quantitative analysis of stream stability and scour (FHWA, 1993). Results of a Level I scour investigation also are included in appendix E of this report. A Level I investigation provides a qualitative geomorphic characterization of the study site. Information on the bridge, gleaned from Vermont Agency of Transportation (VTAOT) files, was compiled prior to conducting Level I and Level II analyses and is found in appendix D.

The site is in the Green Mountain section of the New England physiographic province in southern Vermont. The $17.0-\mathrm{mi}^{2}$ drainage area is in a predominantly rural and forested basin. In the vicinity of the study site, the surface cover is forest.

In the study area, the Rake Branch Deerfield River has an incised, straight channel with a slope of approximately $0.008 \mathrm{ft} / \mathrm{ft}$, an average channel top width of $55 \mathrm{ft}$ and an average bank height of $3 \mathrm{ft}$. The channel bed material ranges from gravel to boulders with a median grain size $\left(\mathrm{D}_{50}\right)$ of $106.2 \mathrm{~mm}(0.348 \mathrm{ft})$. The geomorphic assessment at the time of the Level I and Level II site visit on August 7, 1996, indicated that the reach was stable.

The Town Highway 1 crossing of the Rake Branch Deerfield River is a 45-ft-long, one-lane bridge consisting of one 38-foot steel-beam span (Vermont Agency of Transportation, written communication, September 28, 1995). The opening length of the structure parallel to the bridge face is $35.3 \mathrm{ft}$. The bridge is supported by vertical, concrete abutments with wingwalls. The channel is not skewed to the opening and the opening-skew-to-roadway is zero degrees.

The only scour protection measure at the site was type- 2 stone fill (less than 36 inches diameter) along the upstream left wingwall, downstream left and right wingwalls, and at the upstream end of the upstream right wingwall. Additional details describing conditions at the site are included in the Level II Summary and appendices D and E. 
Scour depths and recommended rock rip-rap sizes were computed using the general guidelines described in Hydraulic Engineering Circular 18 (Richardson and Davis, 1995) for the 100- and 500-year discharges. In addition, the incipient roadway-overtopping discharge was determined and analyzed as another potential worst-case scour scenario. Total scour at a highway crossing is comprised of three components: 1) long-term streambed degradation; 2) contraction scour (due to accelerated flow caused by a reduction in flow area at a bridge) and; 3) local scour (caused by accelerated flow around piers and abutments). Total scour is the sum of the three components. Equations are available to compute depths for contraction and local scour and a summary of the results of these computations follows.

Contraction scour for all modelled flows ranged from 0.1 to $0.4 \mathrm{ft}$. The worst-case contraction scour occurred at the 100-year discharge. Abutment scour ranged from 9.0 to $15.6 \mathrm{ft}$. The worst-case abutment scour occurred at the 500-year discharge. Additional information on scour depths and depths to armoring are included in the section titled "Scour Results". Scoured-streambed elevations, based on the calculated scour depths, are presented in tables 1 and 2. A cross-section of the scour computed at the bridge is presented in figure 8. Scour depths were calculated assuming an infinite depth of erosive material and a homogeneous particle-size distribution.

It is generally accepted that the Froehlich equation (abutment scour) gives "excessively conservative estimates of scour depths" (Richardson and Davis, 1995, p. 46). Usually, computed scour depths are evaluated in combination with other information including (but not limited to) historical performance during flood events, the geomorphic stability assessment, existing scour protection measures, and the results of the hydraulic analyses. Therefore, scour depths adopted by VTAOT may differ from the computed values documented herein. 


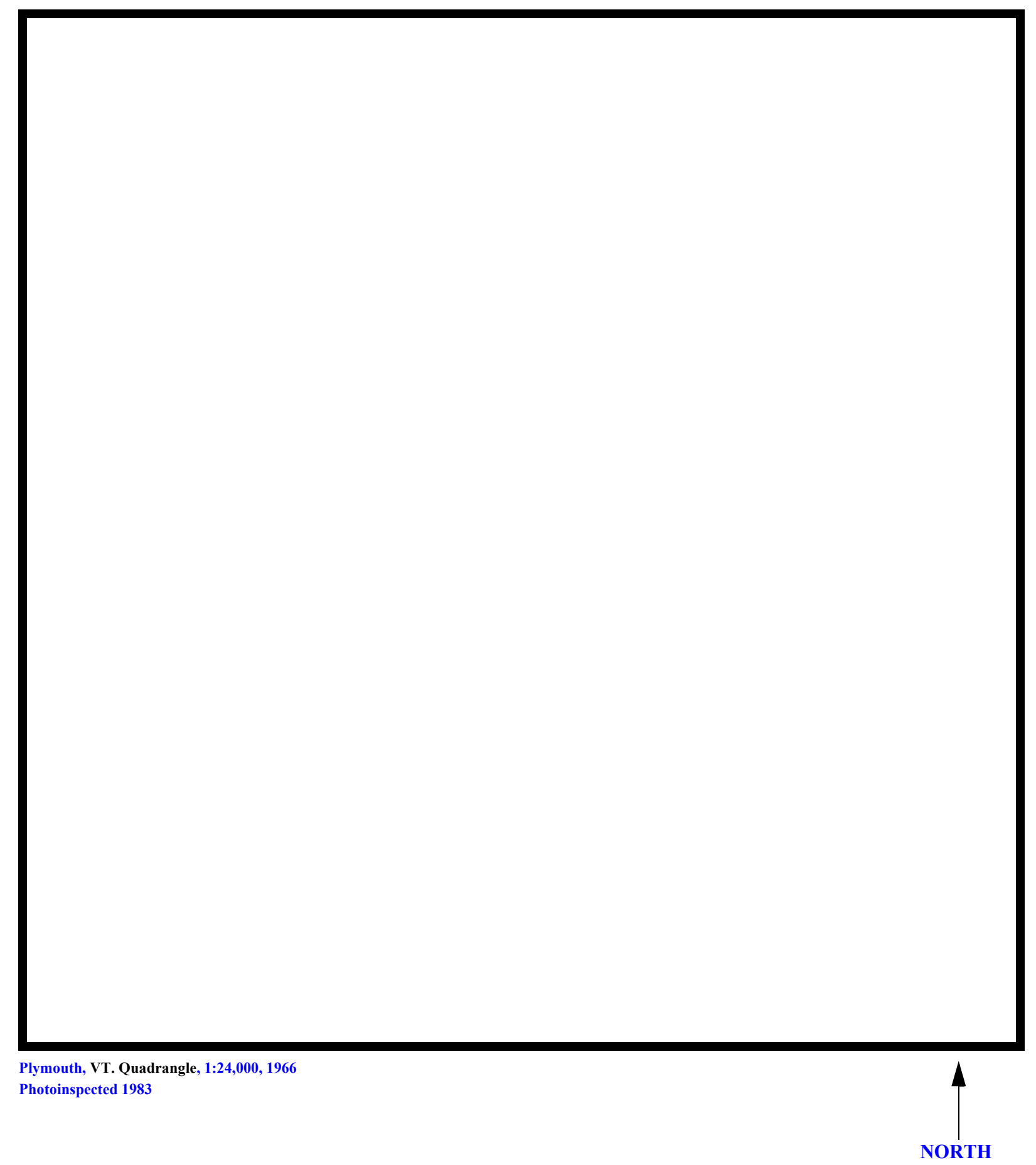

Figure 1. Location of study area on USGS 1:24,000 scale map. 
Figure 2. Location of study area on Vermont Agency of Transportation town highway map. 

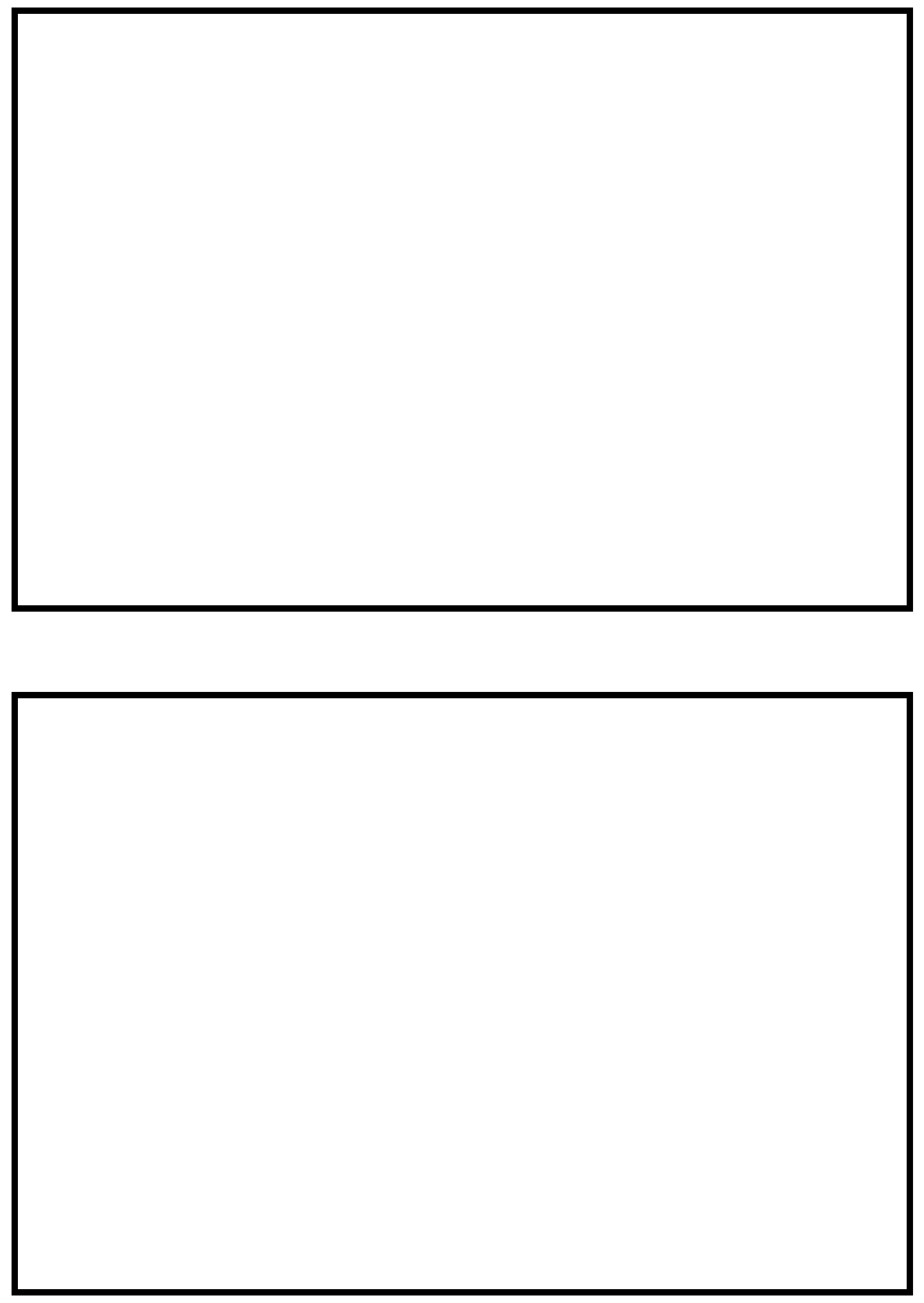

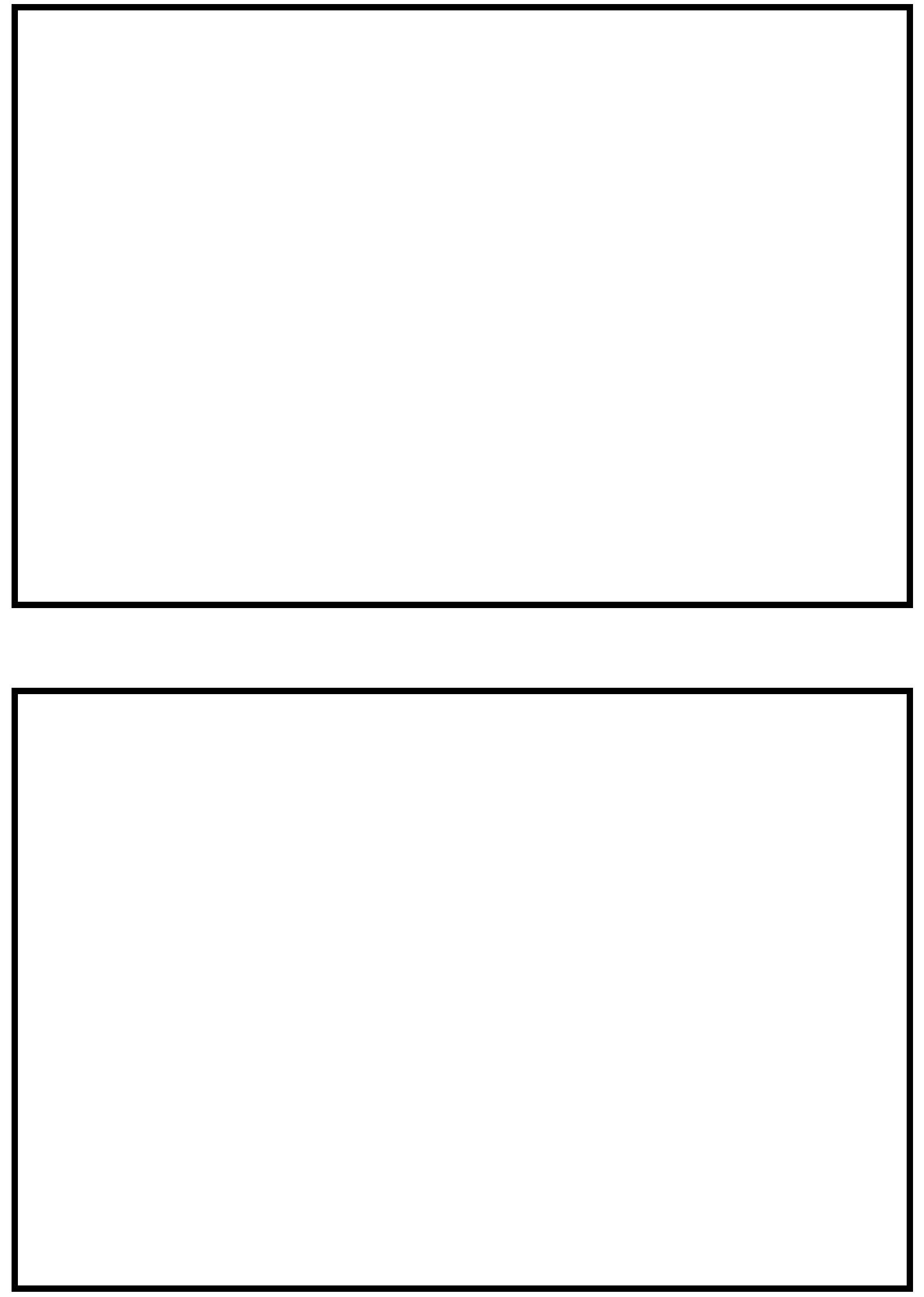


\section{LEVEL II SUMMARY}

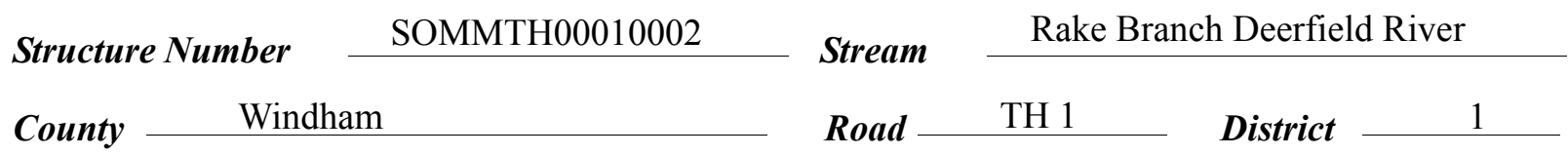

\section{Description of Bridge}

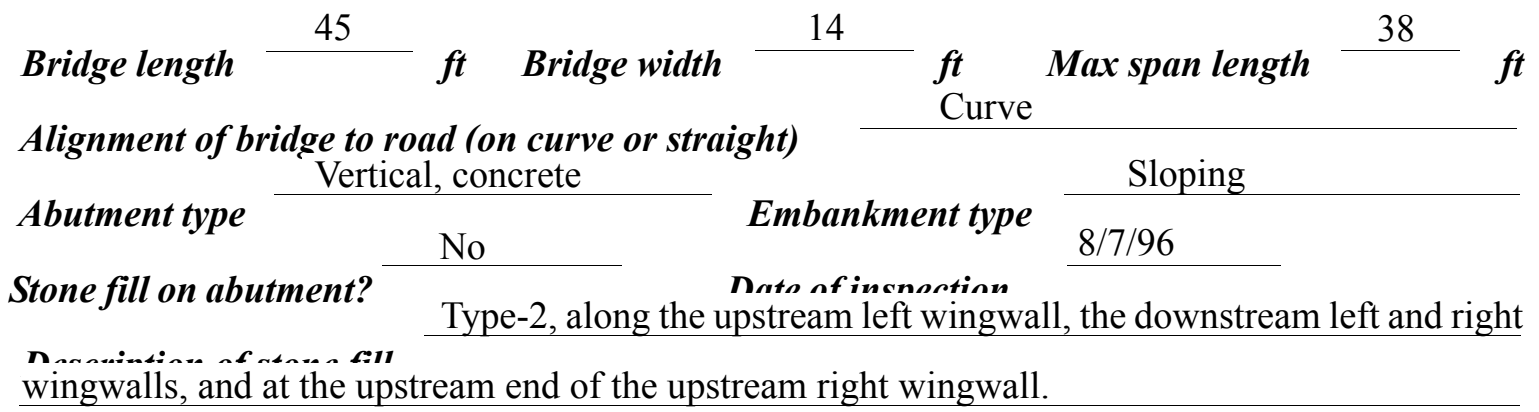

Abutments and wingwalls are concrete. There are concrete filled bags along the left and right abutments and upstream wingwalls.

Is bridge skewed to flood flow according to No 'survey?

Debris accumulation on bridge at time of Level I or Level II site visit:

\begin{tabular}{|c|c|c|c|}
\hline & $\begin{array}{c}\text { Date af incnortion } \\
8 / 7 / 96 \\
\end{array}$ & $\begin{array}{l}\text { Percent of rhommal } \\
\text { blocked ingrtzontatly }\end{array}$ & $\begin{array}{l}\text { Percent of } 0 \\
\text { blocked verticatty }\end{array}$ \\
\hline & $8 / 7 / 96$ & 0 & 0 \\
\hline & Moderate. & & \\
\hline
\end{tabular}

\section{Potential for debris}

An overflow channel on the right bank diverts some water at high flows away from the bridge Doscriho anv, foaturos noar ar at tho hridos that mav, affoct flou, (includo ahsorvation dato) and through two culverts under the right road approach, observed on 8/7/96. 


\section{Description of the Geomorphic Setting}

General topography The channel is located within a moderate relief valley with narrow flood plains.

Geomorphic conditions at bridge site: downstream (DS), upstream (US)

Date of inspection $\quad 8 / 7 / 96$

DS left: $\quad$ Moderately sloped overbank and steep valley wall

DS right: $\quad$ Narrow flood plain

US left: $\quad$ Moderately sloped overbank and steep valley wall

US right: $\frac{\text { Narrow flood plain }}{\text { Description of the Channel }}$

$\begin{array}{llll}\text { Average top width } & 55 & \text { Average depth } & \frac{3}{\text { Cobbles/Gravel }} \\ & \text { Cobbles/Gravel }\end{array}$

Predominant bed material Bank material Perennial, straight

and stable with non-alluvial channel boundaries and narrow point bär.

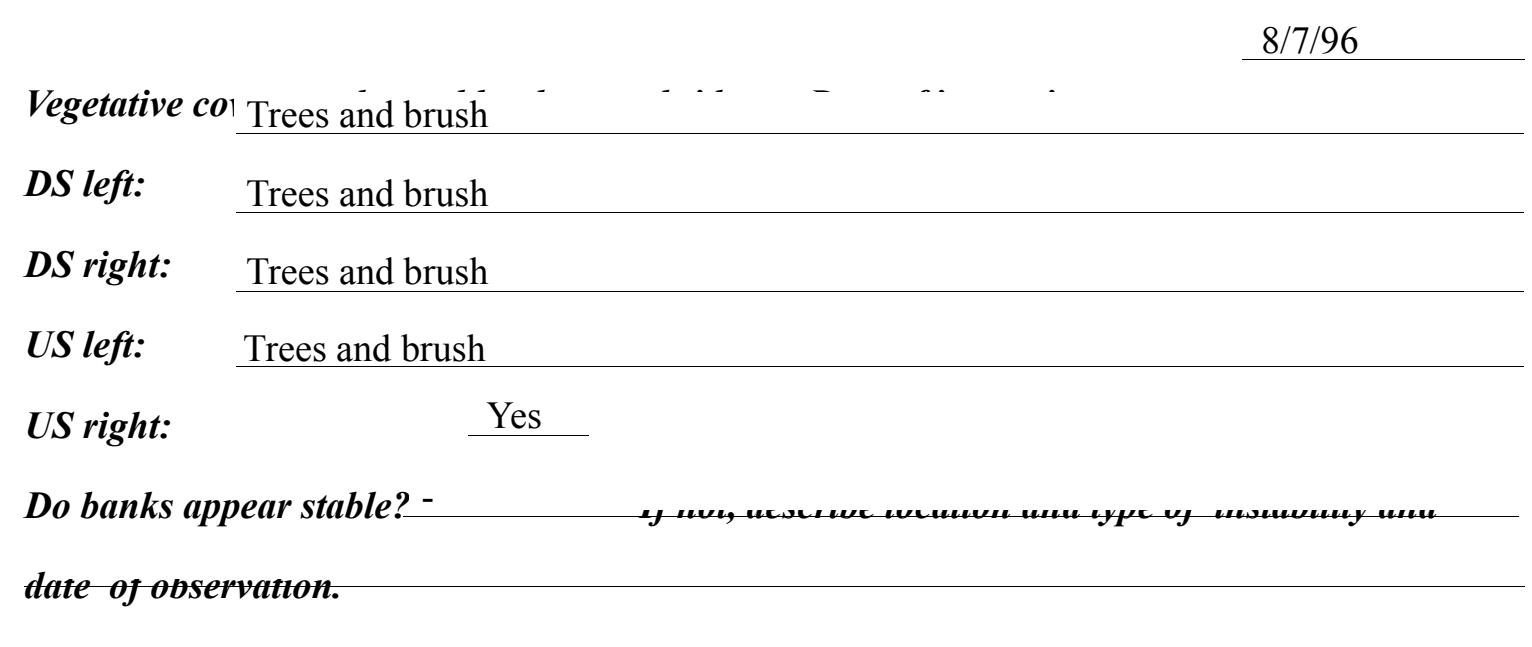

None noted on

$8 / 7 / 96$.

Describe any obstructions in channel and date of observation. 


\title{
Hydrology
}

Drainage area $\frac{17.0}{m^{2}}{ }^{2}$

Percentage of drainage area in physiographic provinces: (approximate)

Physiographic province/section

New England/Green Mountain
Percent of drainage area 100

\begin{abstract}
Is drainage area considered rural or urban? Rural _ Describe any significant urbanization: None.
\end{abstract}

Is there a USGS gage on the stream of interest?

No

\section{USGS gage description}

USGS gage number

Gage drainage area $\mathrm{mi}^{2}$

Is there a lake/p

\section{Calculated Discharges $\quad \underline{4,700}$ \\ Q100 $\quad \mathrm{ft}^{3} / \mathrm{s}$ \\ Q500 $\quad \mathrm{ft}^{3} / \mathrm{s}$}

The 100- and 500-year discharges are the median methods (Benson, 1962; Johnson and Tasker, 1974; FHWA, 1983; Potter, 1957a\&b; Talbot,

1887). Each curve was extended graphically to the 500-year event. 


\section{Description of the Water-Surface Profile Model (WSPRO) Analysis}

Datum for WSPRO analysis (USGS survey, sea level, VTAOT plans)

USGS survey

Datum tie between USGS survey and VTAOT plans

None

Description of reference marks used to determine USGS datum. $\quad$ RM1 is a chiseled X on top of the upstream end of the left abutment (elev. $508.22 \mathrm{ft}$, arbitrary survey datum). RM2 is a chiseled X on top of the upstream end of the right abutment (elev. $507.77 \mathrm{ft}$, arbitrary survey

datum).

\section{Cross-Sections Used in WSPRO Analysis}

\begin{tabular}{|c|c|c|c|}
\hline${ }^{1}$ Cross-section & $\begin{array}{c}\text { Section } \\
\text { Reference } \\
\text { Distance } \\
\text { (SRD) in feet }\end{array}$ & $\begin{array}{c}{ }^{2} \text { Cross-section } \\
\text { development }\end{array}$ & Comments \\
\hline EXITX & -39 & 1 & Exit section \\
\hline FULLV & 0 & 2 & $\begin{array}{l}\text { Downstream Full-valley } \\
\text { section (Templated from } \\
\text { EXITX) }\end{array}$ \\
\hline BRIDG & 0 & 1 & Bridge section \\
\hline RDWAY & 11 & 1 & Road Grade section \\
\hline APTEM & 52 & 1 & $\begin{array}{l}\text { Approach section as sur- } \\
\text { veyed (Used as a tem- } \\
\text { plate) }\end{array}$ \\
\hline APPRO & 58 & 2 & $\begin{array}{l}\text { Modelled Approach sec- } \\
\text { tion (Templated from } \\
\text { APTEM) }\end{array}$ \\
\hline
\end{tabular}

${ }^{1}$ For location of cross-sections see plan-view sketch included with Level I field form, Appendix E. For more detail on how cross-sections were developed see WSPRO input file. 


\section{Data and Assumptions Used in WSPRO Model}

Hydraulic analyses of the reach were done by use of the Federal Highway Administration's WSPRO step-backwater computer program (Shearman and others, 1986, and Shearman, 1990). The analyses reported herein reflect conditions existing at the site at the time of the study. Furthermore, in the development of the model it was necessary to assume no accumulation of debris or ice at the site. Results of the hydraulic model are presented in the Bridge Hydraulic Summary, appendix B, and figure 7.

Channel roughness factors (Manning's " $n$ ") used in the hydraulic model were estimated using field inspections at each cross section following the general guidelines described by Arcement and Schneider (1989). Final adjustments to the values were made during the modelling of the reach. Channel " $\mathrm{n}$ " values for the reach ranged from 0.050 to 0.060 , and overbank " $\mathrm{n}$ " values ranged from 0.080 to 0.090 .

Normal depth at the exit section (EXITX) was assumed as the starting water surface. This depth was computed by use of the slope-conveyance method outlined in the user's manual for WSPRO (Shearman, 1990). The slope used was $0.0077 \mathrm{ft} / \mathrm{ft}$, which was estimated from surveyed thalweg points downstream of the bridge.

The surveyed approach section (APTEM) was moved along the approach channel slope $(0.0230 \mathrm{ft} / \mathrm{ft})$ to establish the modelled approach section (APPRO), one bridge length upstream of the upstream face as recommended by Shearman and others (1986). This location provides a consistent method for determining scour variables.

Culvert routines provided with WSPRO are not fully integrated. Therefore, it was necessary to develop individual ratings for the culvert and bridge to model this multipleopening situation. The ratings were combined to determine the quantity of the total discharge diverted from the bridge through the culverts. The combined ratings indicate the culverts divert $5.5 \%$ of the total peak discharge on average. Each modelled discharge was reduced by the flow through the culverts for the model provided in appendices A and B. 


\section{Bridge Hydraulics Summary}

\begin{tabular}{llll} 
Average bridge embankment elevation & 509.7 & $f t$ \\
\cline { 3 - 3 } Average low steel elevation & 508.1 & $\boldsymbol{f t}$
\end{tabular}

100-year discharge $\quad 3,250 \quad \mathrm{ft}^{3} / \mathrm{s}$

Water-surface elevation in bridge opening $\quad 503.1 \quad f t$

Road overtopping? ___ Yes Discharge over road __ $220,3 / s$

Area of flow in bridge opening $\quad 223 \quad \mathrm{ft}^{2}$

Average velocity in bridge opening $12.7 \quad \mathrm{ft} / \mathrm{s}$

$\begin{array}{llll}\text { Maximum WSPRO tube velocity at bridge } & 15.8 \mathrm{ft} / \mathrm{s}\end{array}$

Water-surface elevation at Approach section with bridge 506.9

Water-surface elevation at Approach section without bridge

Amount of backwater caused by bridge $\quad 2.6 \quad$ it

\section{3}

500-year discharge $\quad 4,700 \quad \mathrm{ft}^{3} / \mathrm{s}$

Water-surface elevation in bridge opening

$504.6 f t$

Road overtopping? ___ Yes Discharge over road _ $1,080, \ldots / s$

Area of flow in bridge opening $\quad 275 \quad \mathrm{ft}^{2}$

Average velocity in bridge opening $12.5 \mathrm{ft} / \mathrm{s}$

Maximum WSPRO tube velocity at bridge 15.9 's

Water-surface elevation at Approach section with bridge

Water-surface elevation at Approach section without bridge

Amount of backwater caused by bridge $\quad 2.9$,

508.1

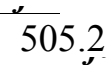

Incipient overtopping discharge $\quad 2,580 \mathrm{ft}^{3} / \mathrm{s}$

Water-surface elevation in bridge opening $\quad 502.5 \quad t$

Area of flow in bridge opening $\quad 204 \quad \mathrm{ft}^{2}$

Average velocity in bridge opening $\quad 11.8 \mathrm{ft} / \mathrm{s}$

Maximum WSPRO tube velocity at bridge $14.5 \mathrm{ft} / \mathrm{s}$

Water-surface elevation at Approach section with bridge

Water-surface elevation at Approach section without bridge

505.9

Amount of backwater caused by bridge $\quad 2.1$ it 


\section{Scour Analysis Summary}

\section{Special Conditions or Assumptions Made in Scour Analysis}

Scour depths were computed using the general guidelines described in Hydraulic Engineering Circular 18 (Richardson and Davis, 1995). Scour depths were calculated assuming an infinite depth of erosive material and a homogeneous particle-size distribution. The results of the scour analyses for the 100- and 500-year discharges are presented in tables 1 and 2 and the scour depths are shown graphically in figure 8 .

Contraction scour for the 100-year, 500-year, and incipient roadway-overtopping discharges was computed by use of the Laursen clear-water contraction scour equation (Richardson and Davis, 1995, p. 32, equation 20). The streambed armoring depths computed suggest that armoring will not limit the depth of contraction scour.

Abutment scour was computed by use of the Froehlich equation (Richardson and Davis, 1995, p. 48, equation 28). Variables for the Froehlich equation include the Froude number of the flow approaching the embankments, the length of the embankment blocking flow, and the depth of flow approaching the embankment less any roadway overtopping. 


\section{Scour Results}

Contraction scour:

Main channel

Live-bed scour

Clear-water scour

Depth to armoring

Left overbank

Right overbank

Local scour:

Abutment scour

Left abutment

Right abutment

Pier scour

Pier 1

Pier 2

Pier 3 100-year
discharge 500-year discharge

(Scour depths in feet)

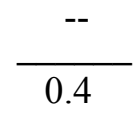

$$
16.7^{-}
$$
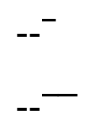

11.2

13.5

14.1

$15.6-$

12.3-
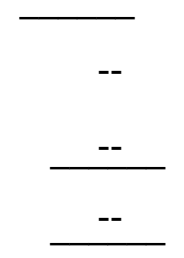

Incipient overtopping discharge 


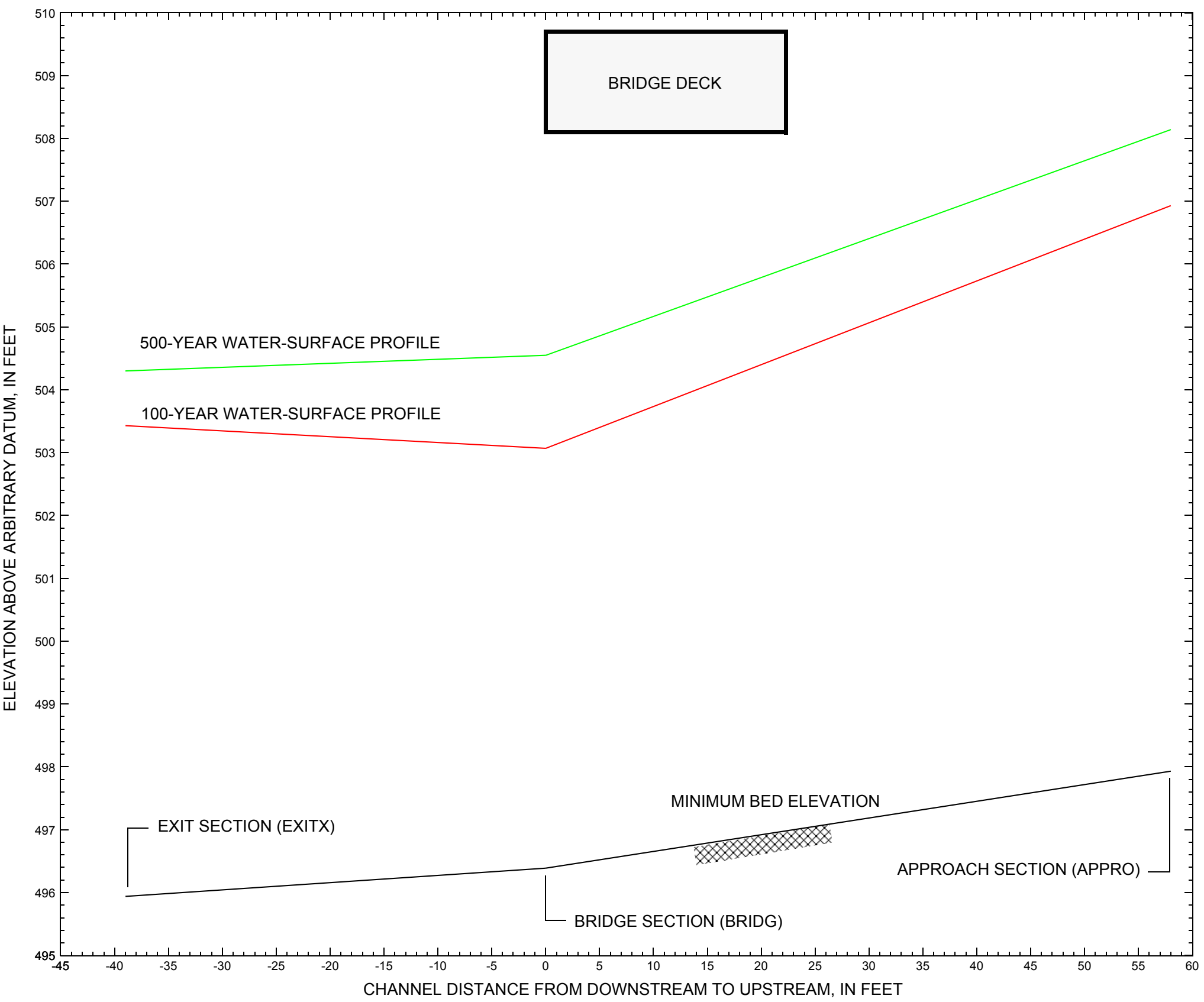

Figure 7. Water-surface profiles for the 100- and 500-year discharges at structure SOMMTH00010002 on Town Highway 1, crossing the Rake Branch Deerfield River, Somerset, Vermont. 


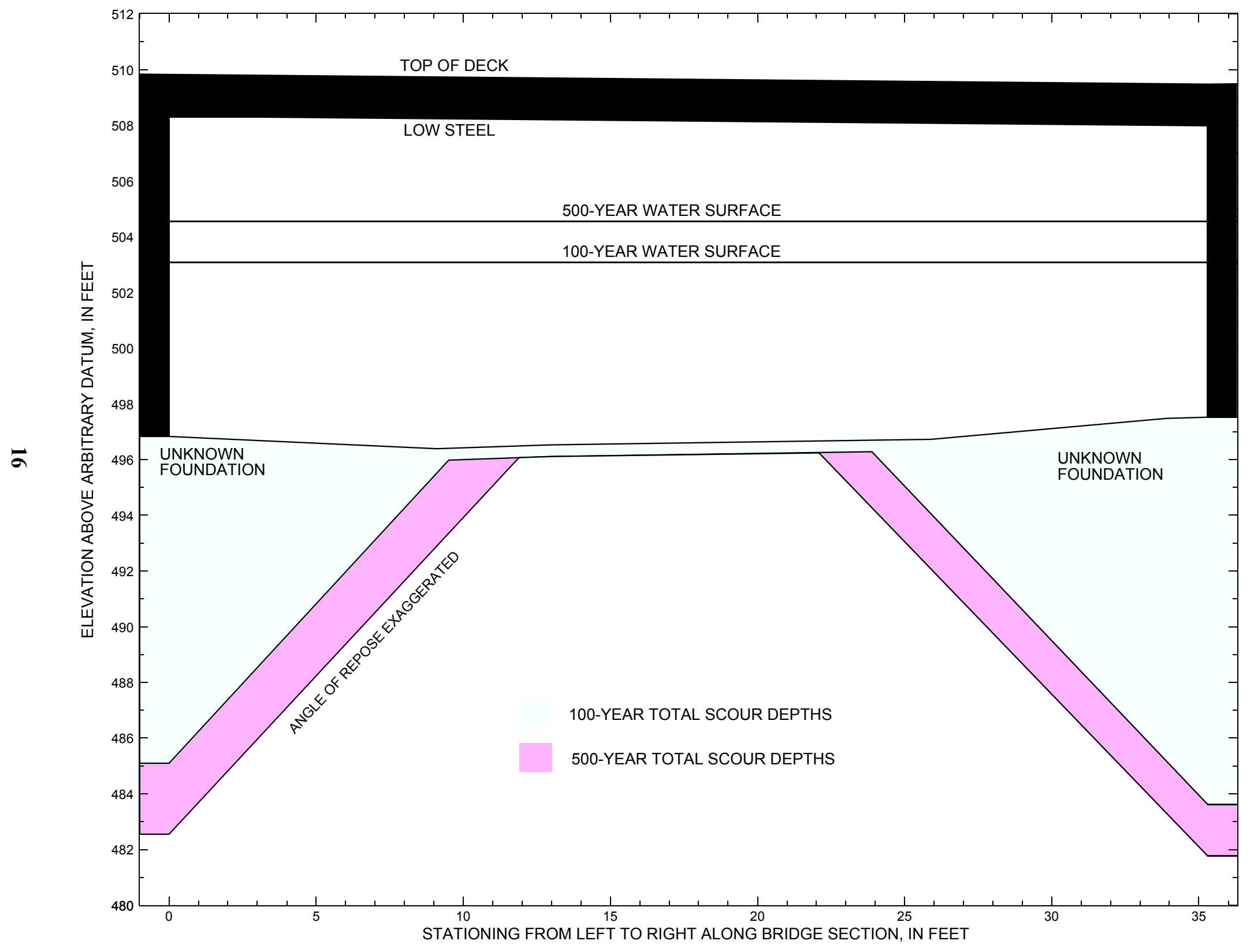

Figure 8. Scour elevations for the 100- and 500-year discharges at structure SOMMTH00010002 on Town Highway 1, crossing the Rake Branch Deerfield River, Somerset, Vermont. 


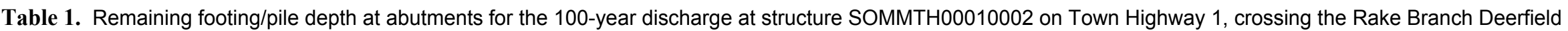
River, Somerset, Vermont.

[VTAOT, Vermont Agency of Transportation; --, no data]

\begin{tabular}{|c|c|c|c|c|c|c|c|c|c|c|c|}
\hline Description & Station $^{1}$ & $\begin{array}{l}\text { VTAOT } \\
\text { minimum } \\
\text { low-chord } \\
\text { elevation } \\
\text { (feet) }\end{array}$ & $\begin{array}{l}\text { Surveyed } \\
\text { minimum } \\
\text { low-chord } \\
\text { elevation } \\
\text { (feet) }\end{array}$ & $\begin{array}{c}\text { Bottom of } \\
\text { footing/pile } \\
\text { elevation } \\
\text { (feet) }\end{array}$ & $\begin{array}{l}\text { Channel } \\
\text { elevation at } \\
\text { abutment/ } \\
\text { pier }^{2} \\
\text { (feet) }\end{array}$ & $\begin{array}{l}\text { Contraction } \\
\text { scour depth } \\
\text { (feet) }\end{array}$ & $\begin{array}{l}\text { Abutment } \\
\text { scour } \\
\text { depth } \\
\text { (feet) }\end{array}$ & $\begin{array}{l}\text { Pier } \\
\text { scour } \\
\text { depth } \\
\text { (feet) }\end{array}$ & $\begin{array}{l}\text { Depth of } \\
\text { total scour } \\
\text { (feet) }\end{array}$ & $\begin{array}{c}\text { Elevation of } \\
\text { scour }^{2} \\
\text { (feet) }\end{array}$ & $\begin{array}{c}\text { Remaining } \\
\text { footing/pile } \\
\text { depth } \\
\text { (feet) }\end{array}$ \\
\hline \multicolumn{12}{|c|}{100 -year discharge is 3,250 cubic-feet per second } \\
\hline Left abutment & 0.0 & -- & 508.3 & -- & 496.8 & 0.4 & 11.2 & -- & 11.6 & 485.2 & -- \\
\hline Right abutment & 35.3 & -- & 508.0 & -- & 497.5 & 0.4 & 13.5 & -- & 13.9 & 483.6 & -- \\
\hline
\end{tabular}

1.Measured along the face of the most constricting side of the bridge.

2.Arbitrary datum for this study.

Table 2. Remaining footing/pile depth at abutments for the 500-year discharge at structure SOMMTH00010002 on Town Highway 1, crossing the Rake Branch Deerfield River, Somerset, Vermont.

[VTAOT, Vermont Agency of Transportation; --, no data]

\begin{tabular}{|c|c|c|c|c|c|c|c|c|c|c|c|}
\hline Description & Station $^{1}$ & $\begin{array}{l}\text { VTAOT } \\
\text { minimum } \\
\text { low-chord } \\
\text { elevation } \\
\text { (feet) }\end{array}$ & $\begin{array}{l}\text { Surveyed } \\
\text { minimum } \\
\text { low-chord } \\
\text { elevation } \\
\text { (feet) }\end{array}$ & $\begin{array}{c}\text { Bottom of } \\
\text { footing/pile } \\
\text { elevation } \\
\text { (feet) }\end{array}$ & $\begin{array}{c}\text { Channel } \\
\text { elevation at } \\
\text { abutment/ } \\
\text { pier }^{2} \\
\text { (feet) }\end{array}$ & $\begin{array}{l}\text { Contraction } \\
\text { scour depth } \\
\text { (feet) }\end{array}$ & $\begin{array}{l}\text { Abutment } \\
\text { scour } \\
\text { depth } \\
\text { (feet) }\end{array}$ & $\begin{array}{l}\text { Pier } \\
\text { scour } \\
\text { depth } \\
\text { (feet) }\end{array}$ & $\begin{array}{l}\text { Depth of } \\
\text { total scour } \\
\text { (feet) }\end{array}$ & $\begin{array}{c}\text { Elevation of } \\
\text { scour }^{2} \\
\text { (feet) }\end{array}$ & $\begin{array}{c}\text { Remaining } \\
\text { footing/pile } \\
\text { depth } \\
\text { (feet) }\end{array}$ \\
\hline \multicolumn{12}{|c|}{500 -year discharge is 4,700 cubic-feet per second } \\
\hline Left abutment & 0.0 & -- & 508.3 & -- & 496.8 & 0.1 & 14.1 & -- & 14.2 & 482.6 & -- \\
\hline Right abutment & 35.3 & -- & 508.0 & -- & 497.5 & 0.1 & 15.6 & -- & 15.7 & 481.8 & -- \\
\hline
\end{tabular}

1.Measured along the face of the most constricting side of the bridge.

2.Arbitrary datum for this study. 


\section{SELECTED REFERENCES}

Arcement, G.J., Jr., and Schneider, V.R., 1989, Guide for selecting Manning's roughness coefficients for natural channels and flood plains: U.S. Geological Survey Water-Supply Paper 2339, 38 p.

Barnes, H.H., Jr., 1967, Roughness characteristics of natural channels: U.S. Geological Survey Water-Supply Paper 1849,213 p.

Benson, M. A., 1962, Factors Influencing the Occurrence of Floods in a Humid Region of Diverse Terrain: U.S. Geological Survey WaterSupply Paper 1580-B, 64 p.

Brown, S.A. and Clyde, E.S., 1989, Design of riprap revetment: Federal Highway Administration Hydraulic Engineering Circular No. 11, Publication FHWA-IP-89-016, 156 p.

Federal Highway Administration, 1983, Runoff estimates for small watersheds and development of sound design: Federal Highway Administration Report FHWA-RD-77-158.

Federal Highway Administration, 1993, Stream Stability and Scour at Highway Bridges: Participant Workbook: Federal Highway Administration Report FHWA-HI-91-011.

Froehlich, D.C., 1989, Local scour at bridge abutments in Ports, M.A., ed., Hydraulic Engineering--Proceedings of the 1989 National Conference on Hydraulic Engineering: New York, American Society of Civil Engineers, p. 13-18.

Hayes, D.C.,1993, Site selection and collection of bridge-scour data in Delaware, Maryland, and Virginia: U.S. Geological Survey WaterResources Investigation Report 93-4017, 23 p.

Interagency Advisory Committee on Water Data, 1982, Guidelines for determining flood flow frequency: U.S. Geological Survey, Bulletin 17B of the Hydrology Subcommittee, 190 p.

Johnson, C.G. and Tasker, G.D.,1974, Progress report on flood magnitude and frequency of Vermont streams: U.S. Geological Survey OpenFile Report 74-130, 37 p.

Lagasse, P.F., Schall, J.D., Johnson, F., Richardson, E.V., Chang, F., 1995, Stream Stability at Highway Structures: Federal Highway Administration Hydraulic Engineering Circular No. 20, Publication FHWA-IP-90-014, 144 p.

Laursen, E.M., 1960, Scour at bridge crossings: Journal of the Hydraulics Division, American Society of Civil Engineers, v. 86, no. HY2, p. 39-53.

Potter, W. D., 1957a, Peak rates of runoff in the Adirondack, White Mountains, and Maine woods area, Bureau of Public Roads

Potter, W. D., 1957b, Peak rates of runoff in the New England Hill and Lowland area, Bureau of Public Roads

Richardson, E.V. and Davis, S.R., 1995, Evaluating scour at bridges: Federal Highway Administration Hydraulic Engineering Circular No. 18, Publication FHWA-IP-90-017, 204 p.

Richardson, E.V., Simons, D.B., and Julien, P.Y., 1990, Highways in the river environment: Federal Highway Administration Publication FHWA-HI-90-016.

Ritter, D.F., 1984, Process Geomorphology: W.C. Brown Co., Debuque, Iowa, 603 p.

Shearman, J.O., 1990, User's manual for WSPRO--a computer model for water surface profile computations: Federal Highway Administration Publication FHWA-IP-89-027, 187 p.

Shearman, J.O., Kirby, W.H., Schneider, V.R., and Flippo, H.N., 1986, Bridge waterways analysis model; research report: Federal Highway Administration Publication FHWA-RD-86-108, 112 p.

Talbot, A.N., 1887, The determination of water-way for bridges and culverts.

U.S. Geological Survey, 1986, Mount Snow, Vermont 7.5 Minute Series quadrangle map: U.S. Geological Survey Topographic Maps, Scale $1: 24,000$. 


\section{APPENDIX A: \\ WSPRO INPUT FILE}




\section{WSPRO INPUT FILE}

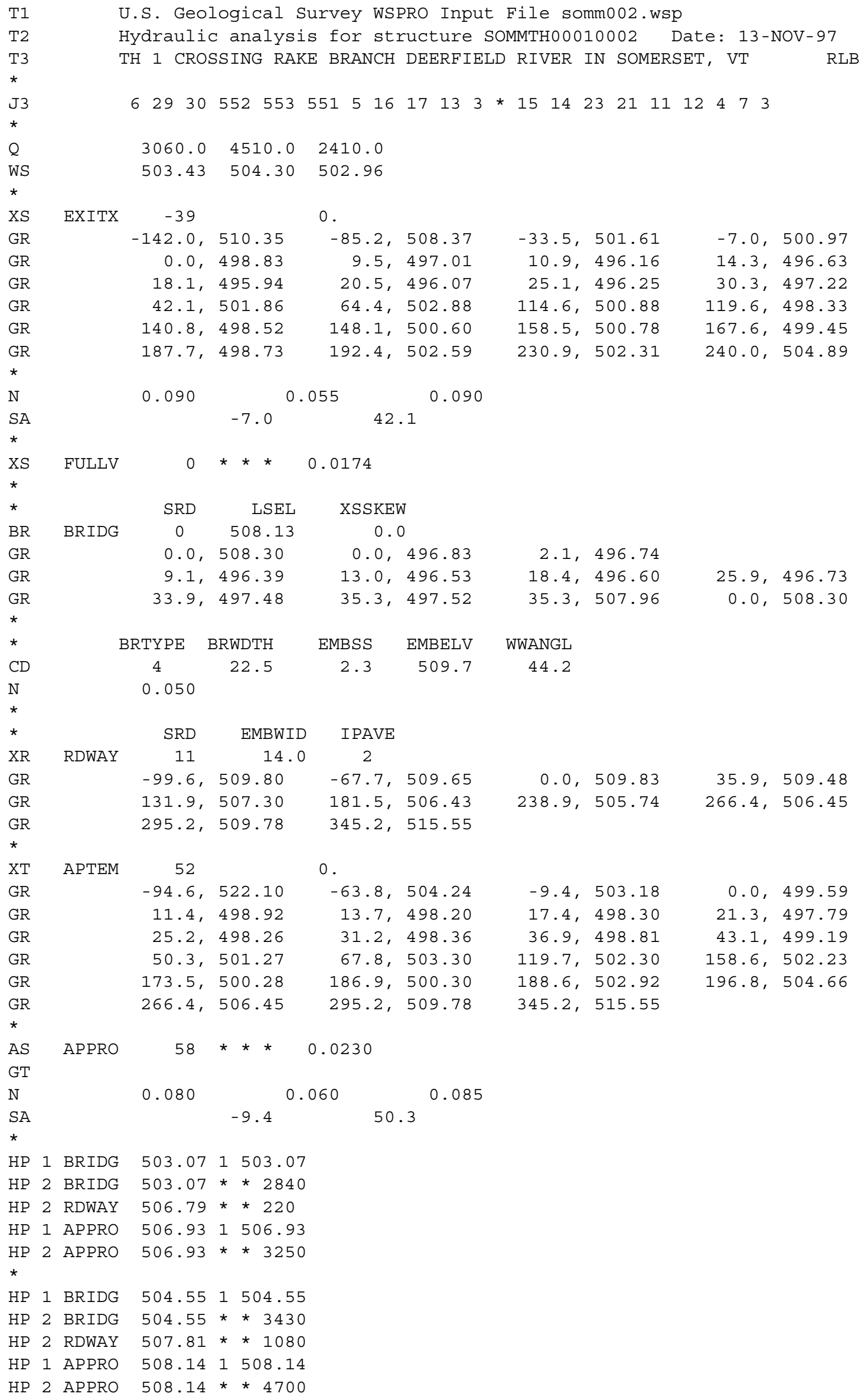




\section{APPENDIX B: \\ WSPRO OUTPUT FILE}




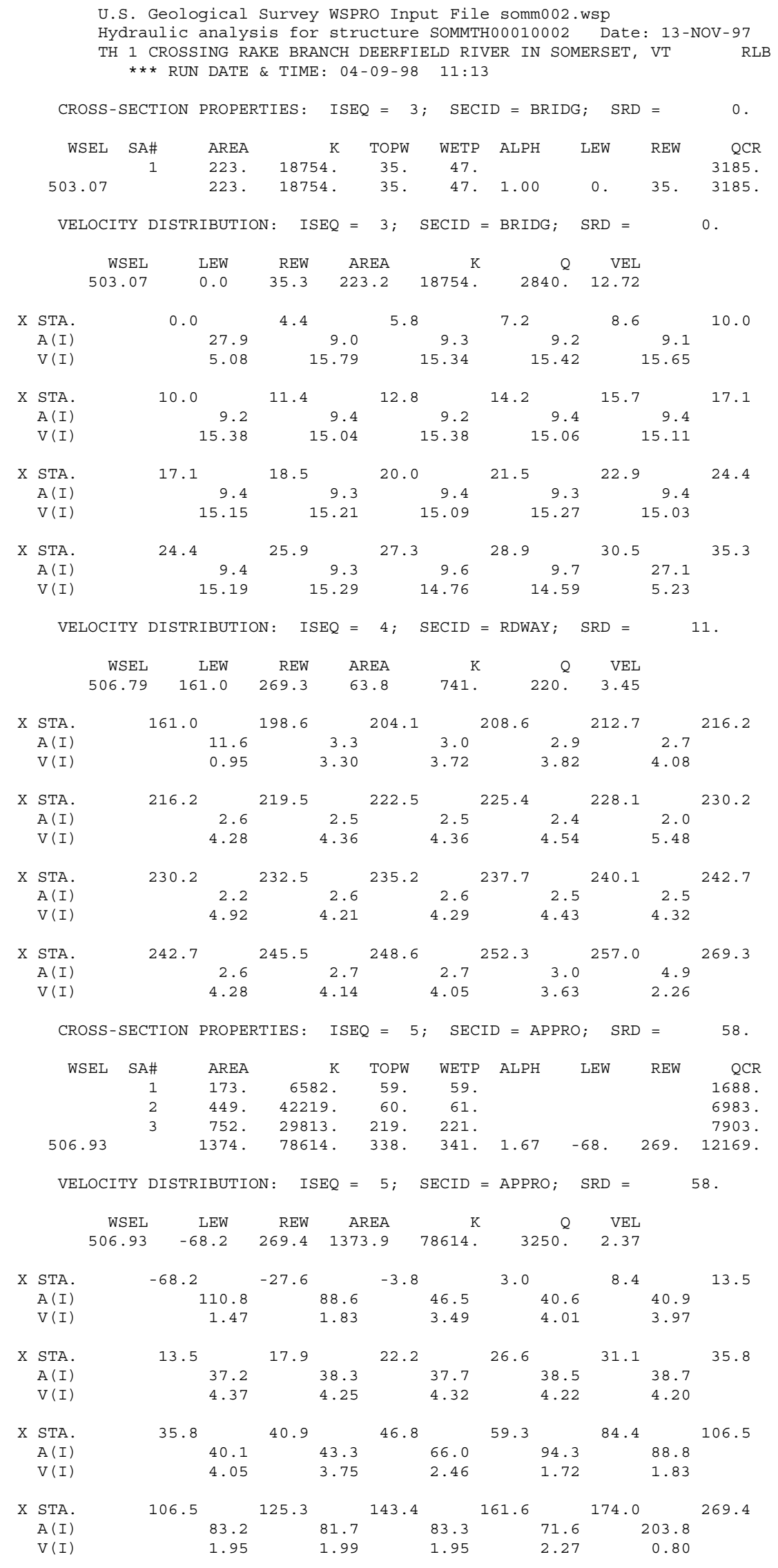




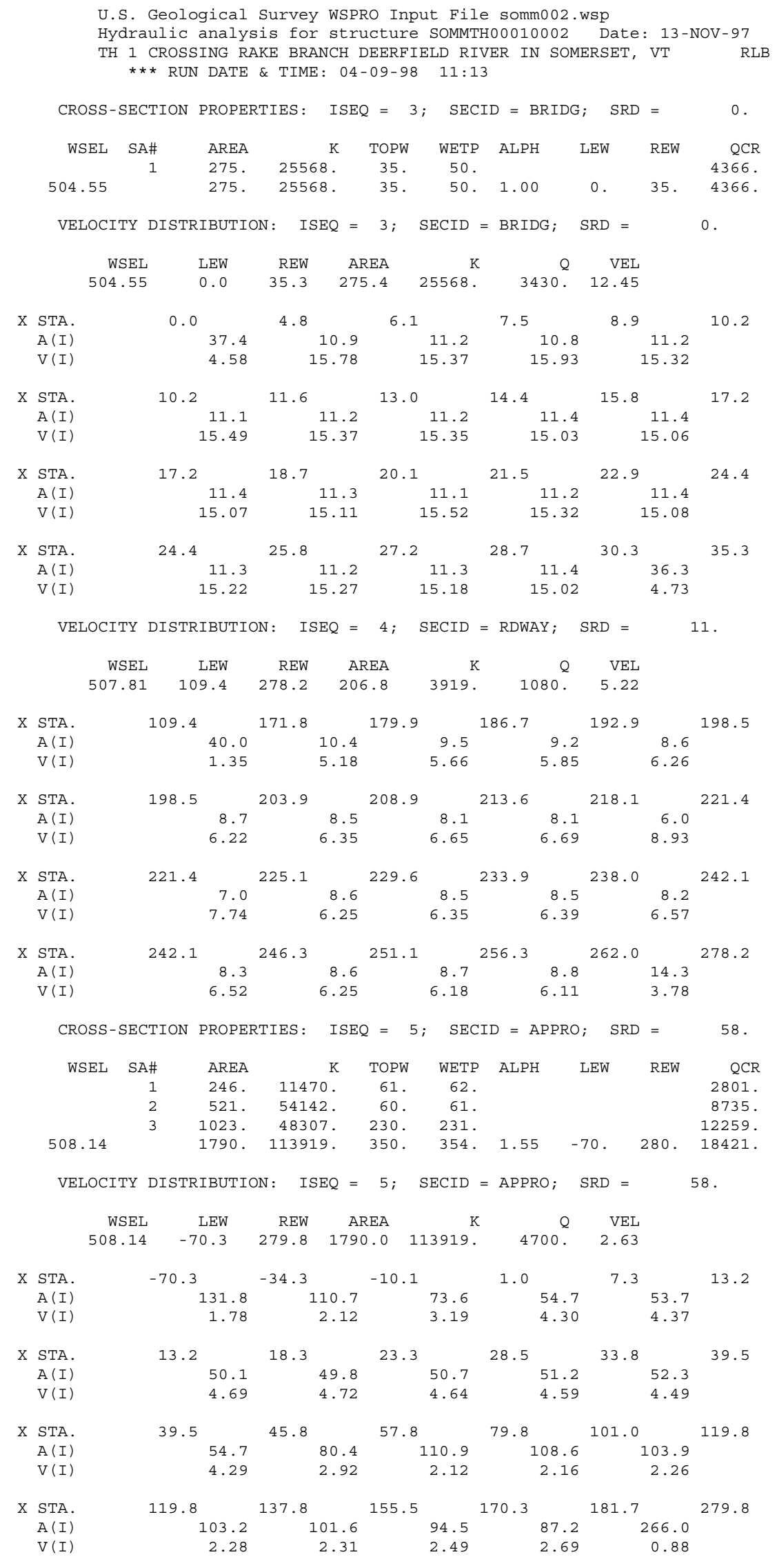


WSPRO OUTPUT FILE (continued)

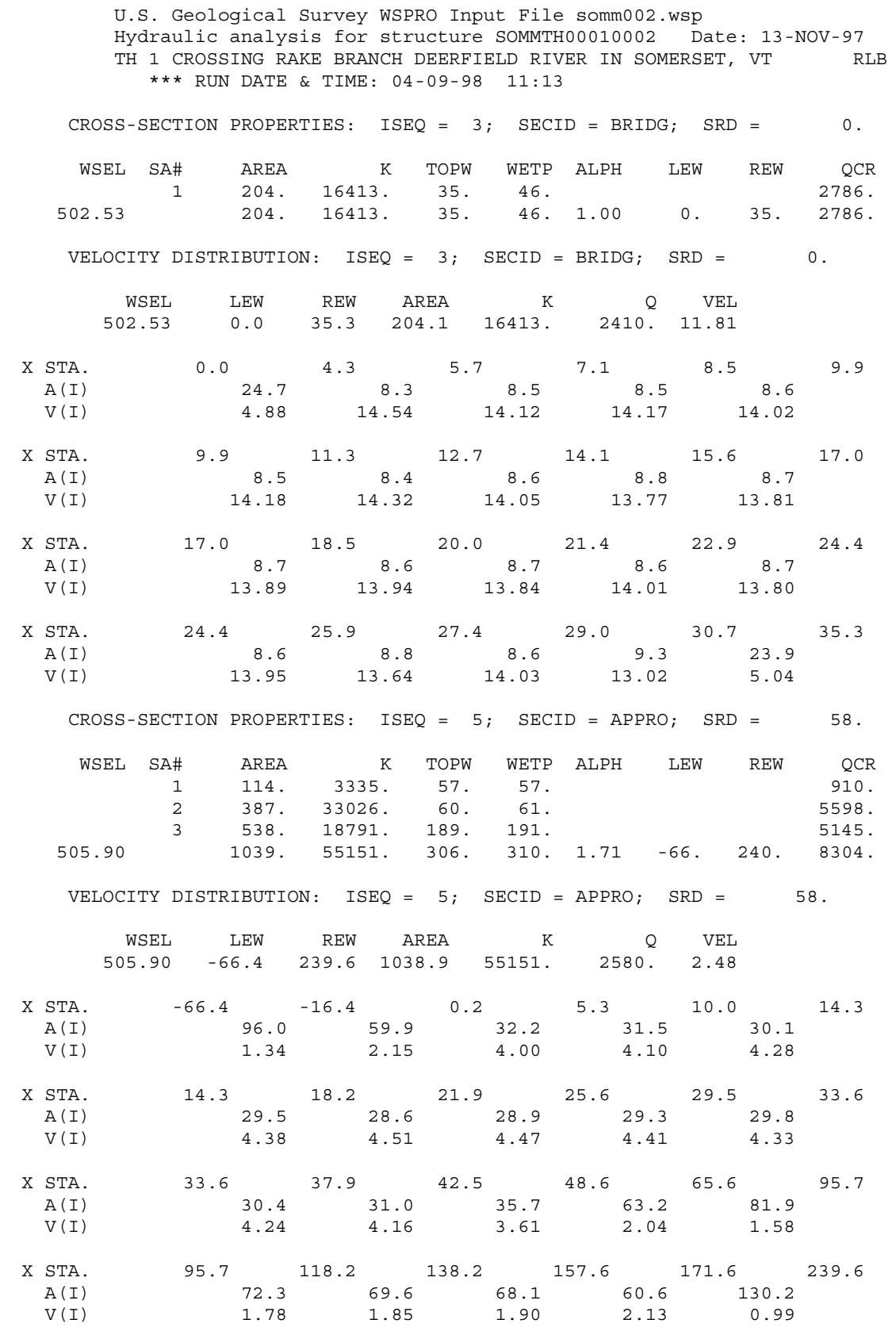


WSPRO OUTPUT FILE (continued)

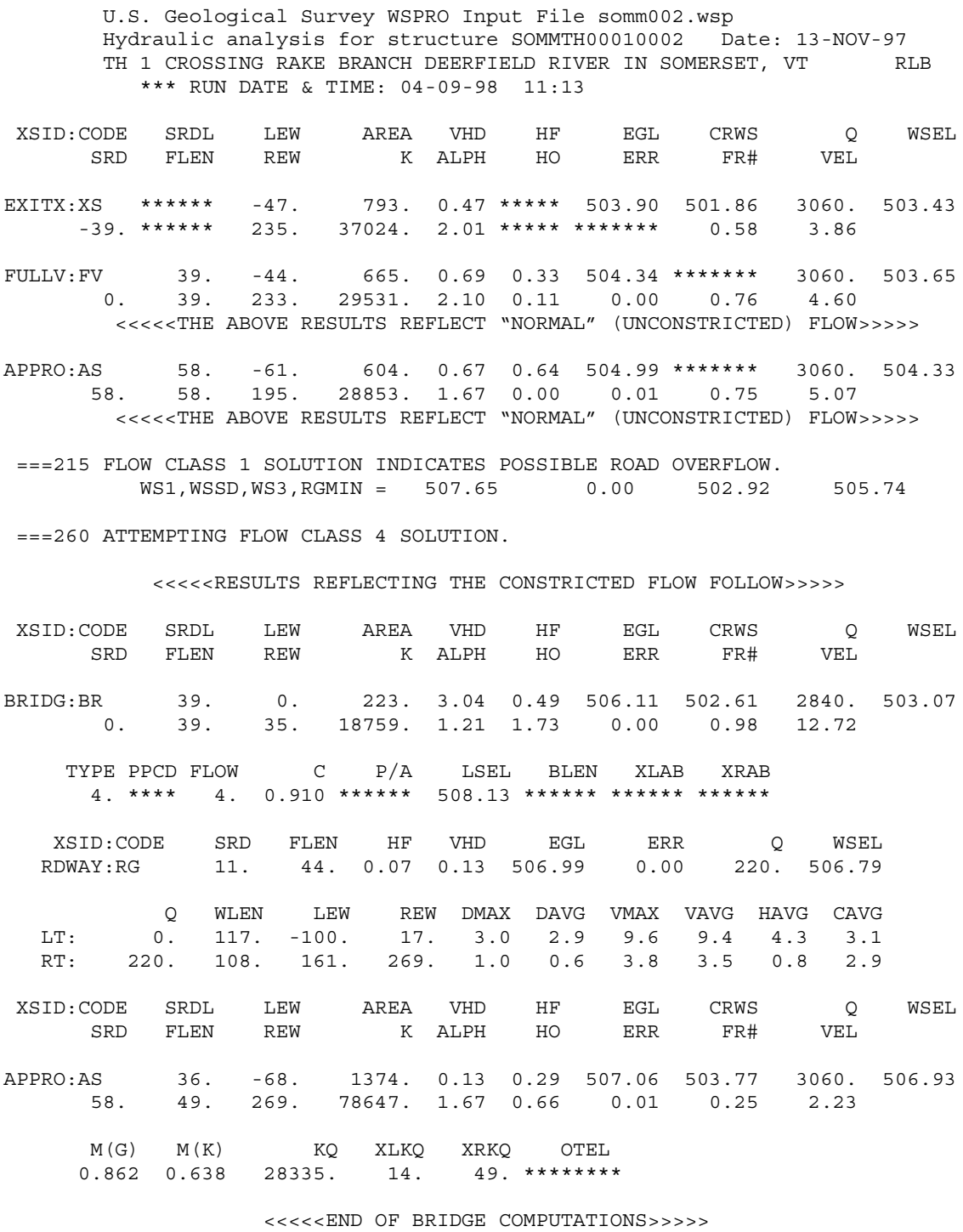


WSPRO OUTPUT FILE (continued)

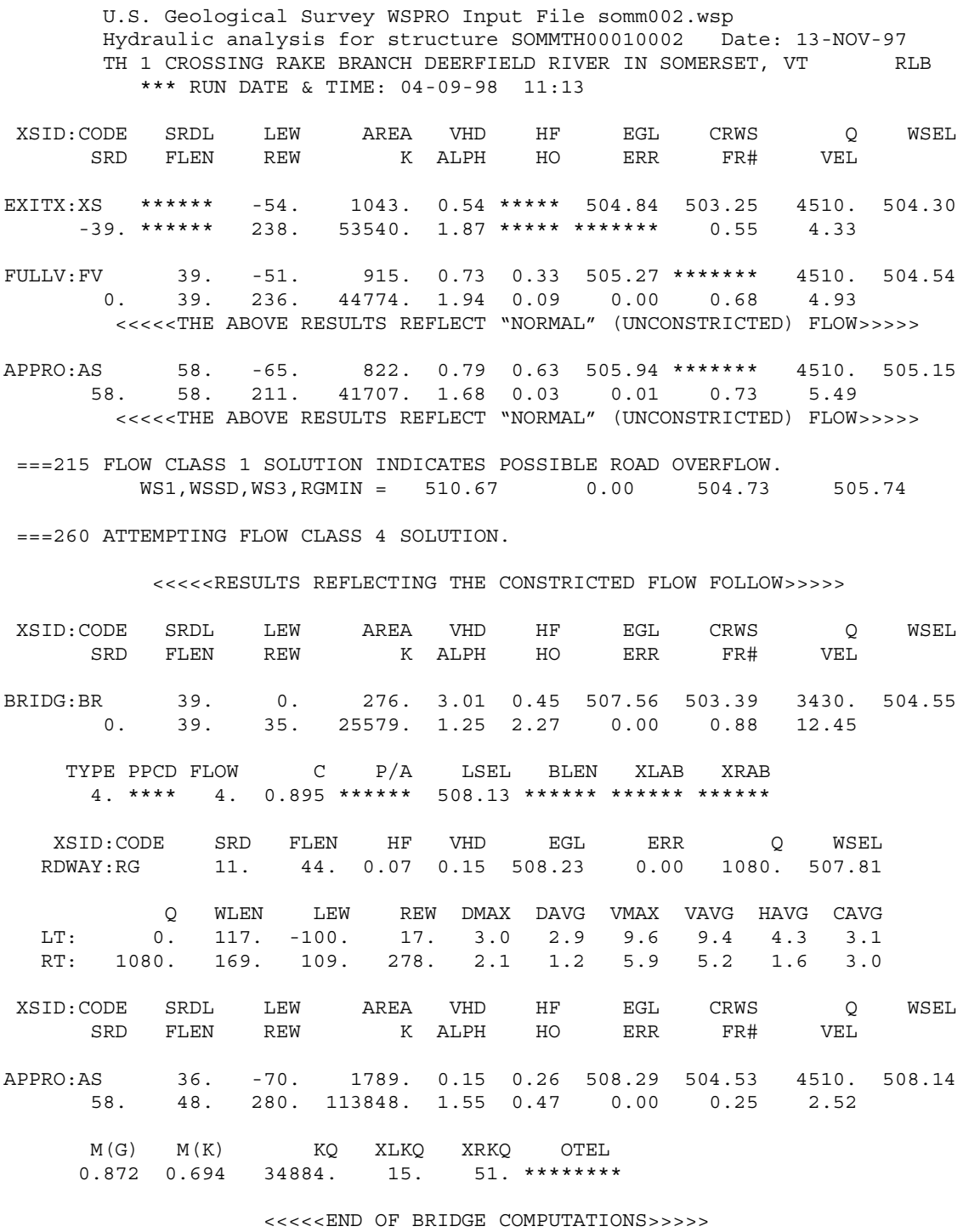


WSPRO OUTPUT FILE (continued)

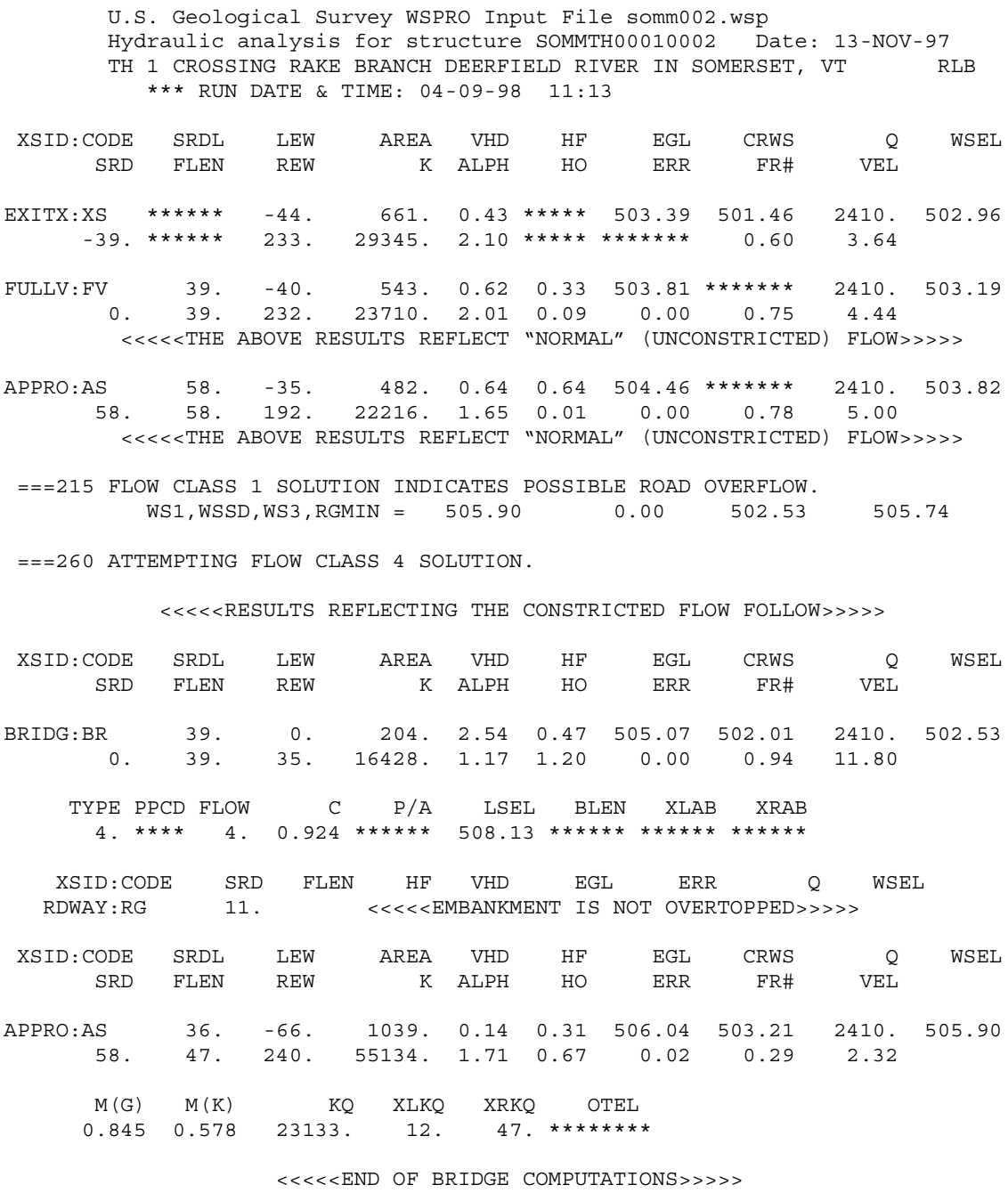

FIRST USER DEFINED TABLE.

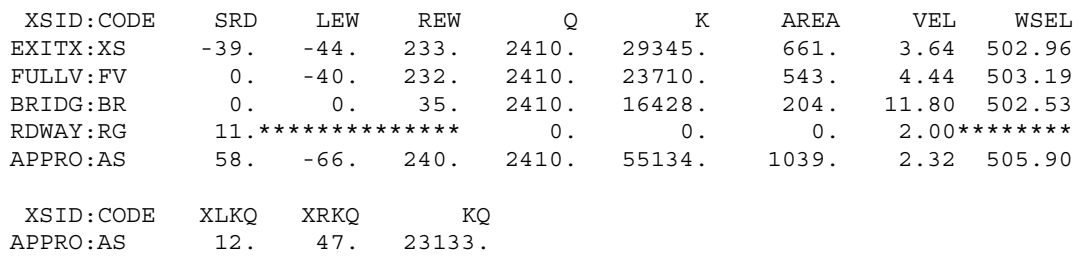

SECOND USER DEFINED TABLE.

$\begin{array}{lrrrrrrrrr}\text { XSID : CODE } & \text { CRWS } & \text { FR\# } & \text { YMIN } & \text { YMAX } & \text { HF } & \text { HO } & \text { VHD } & \text { EGL } & \text { WSEL } \\ \text { EXITX:XS } & 501.46 & 0.60 & 495.94 & 510.35 * * * * * * * * * * & 0.43 & 503.39 & 502.96 \\ \text { FULLV : FV } & * * * * * * * * & 0.75 & 496.62 & 511.03 & 0.33 & 0.09 & 0.62 & 503.81 & 503.19 \\ \text { BRIDG : BR } & 502.01 & 0.94 & 496.39 & 508.30 & 0.47 & 1.20 & 2.54 & 505.07 & 502.53 \\ \text { RDWAY : RG } & * * * * * * * * * * * * * * * * & 505.74 & 515.55 & 0.08 * * * * * * & 0.14 & 505.96 * * * * * * * \\ \text { APPRO:AS } & 503.21 & 0.29 & 497.93 & 522.24 & 0.31 & 0.67 & 0.14 & 506.04 & 505.90\end{array}$




\section{APPENDIX C:}

\section{BED-MATERIAL PARTICLE-SIZE DISTRIBUTION}




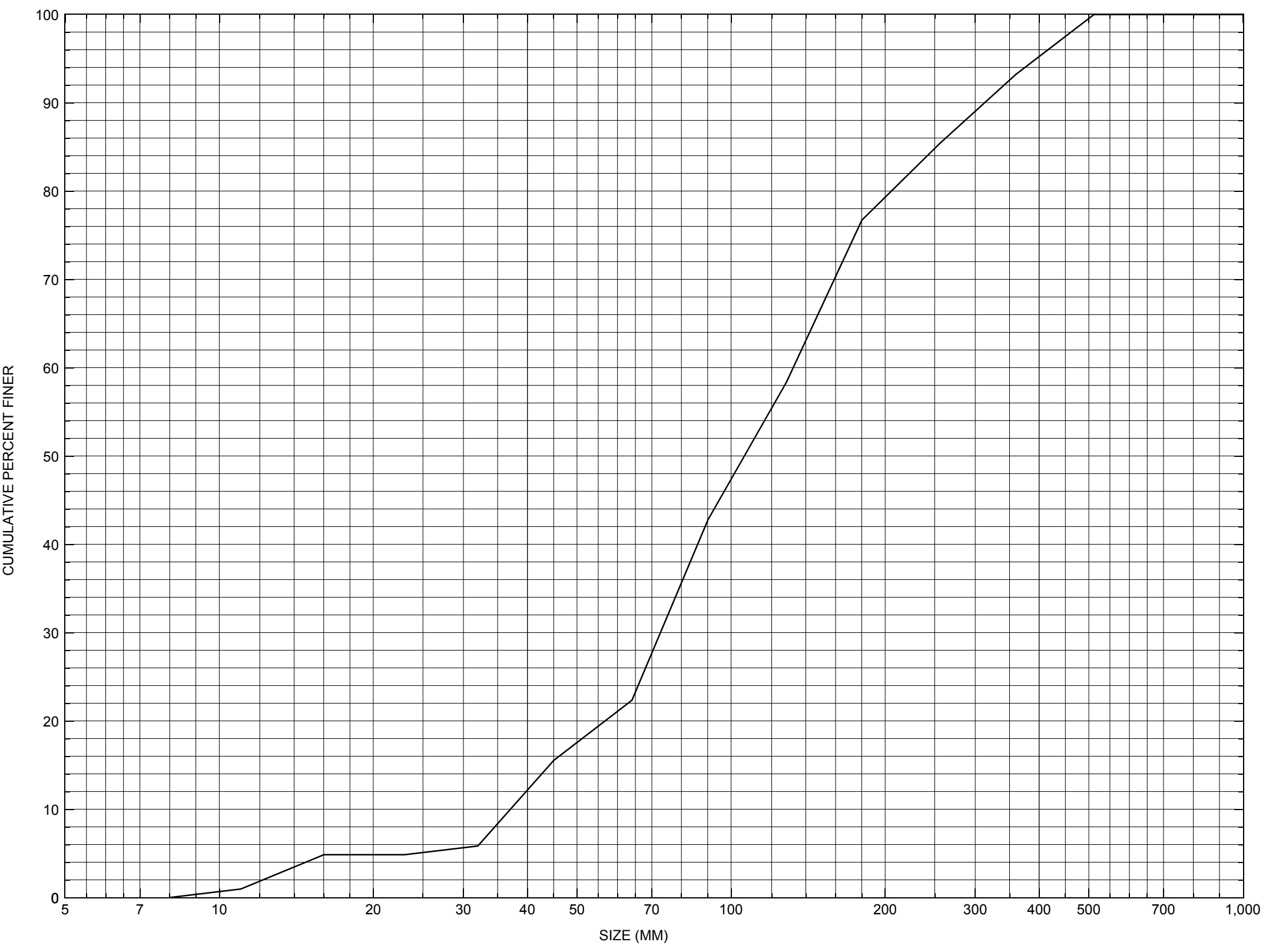

Appendix C. Bed material particle-size distribution for a pebble count in the channel approach of structure SOMMTH00010002, in Somerset, Vermont. 


\section{APPENDIX D: \\ HISTORICAL DATA FORM}




\section{Structure Number SOMMTH00010002}

\section{General Location Descriptive}

Data collected by (First Initial, Full last name) $\underline{\mathbf{L}}$. Medalie

Date $(M M / D D / Y Y) \_09 / \underline{28} / \underline{95}$

Highway District Number $(I-2 ; n n) \underline{01}$

Town (FIPS place code; I - 4; nnnnn) $\mathbf{6 5 7 6 2}$

Waterway (I - 6) RAKE BRANCH DEERFIELD RIVER

Route Number C3001

Topographic Map Mount Snow

Latitude (I - 16; nnnn.n) $\mathbf{4 2 5 6 6}$
County (FIPS county code; I - 3; nnn)

Mile marker (I - 11; nnn.nnn) $\mathbf{0 0 0 0 0 0}$

Road Name (I - 7): -

Vicinity (I - 9) 4.9 MI TO JCT W VT9

Hydrologic Unit Code: $\mathbf{0 1 0 8 0 2 0 3}$

Longitude (i - 17; nnnnn.n) $\mathbf{7 2 5 8 9}$

\section{Select Federal Inventory Codes}

FHWA Structure Number (I - 8) $\mathbf{1 0 1 3 1 5 0 0 0 2 1 3 1 5}$

Maintenance responsibility $(I-21 ; n n) \_$03 _ Maximum span length $(I-48$; $n n n n) \underline{\mathbf{0 0 3 8}}$

Year built (I - 27; YYYY) 1919

Structure length (I - 49; nnnnnn) $\underline{\mathbf{0 0 0 0 4 5}}$

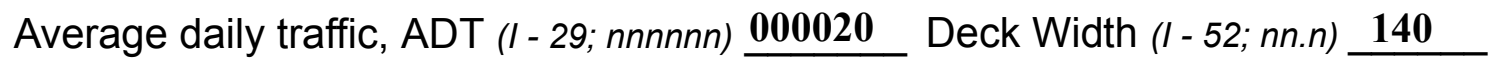

Year of ADT (I - 30; YY) $\mathbf{9 3}$

Channel \& Protection $(I-61 ; n) \underline{5}$

Opening skew to Roadway $(I-34 ; n n) \quad \mathbf{0 0}$

Waterway adequacy $(I-71 ; n) \underline{6}$

Operational status $(I-41 ; X) \quad \mathbf{A}$

Underwater Inspection Frequency $(I-92 B ; X Y Y) \_\mathbf{N}$

Structure type (I- 43; nnn) $\mathbf{3 0 2}$

Year Reconstructed (I - 106) $\mathbf{0 0 0 0}$

Approach span structure type (I - 44; nnn) $\mathbf{0 0 0}$

Clear span (nnn.n ft) $\mathbf{2 9}$

Number of spans (I - 45; nnn) $\underline{\mathbf{0 0 1}}$

Vertical clearance from streambed (nnn.n ft) $\underline{\mathbf{1 1 . 3 3}}$

Number of approach spans (I- 46; nnnn) $\underline{\mathbf{0 0 0 0}}$ Waterway of full opening $\left(n n n . n \mathrm{ft}^{2}\right) \underline{\mathbf{3 2 8 . 5}}$

Comments:

According to the structural inspection report dated 9/10/93, the deck is a concrete filled steel grid with an asphalt overlay. The abutments, wingwalls, and backwalls are concrete. Dirt, gravel and vegetation were reported on the abutments around the fascia beams. Concrete filled bags have been placed along the bottoms of the abutments to correct an undermining/spalling problem. Stone and boulder fill is present around the ends of the wingwalls. There are boulders showing along the US and DS channel embankments. Minor cracks are noted at the abutments, wingwalls, and backwalls. No undermining is noted. Channel scour is noted as 1-1.5 $\mathrm{ft}$ deep at the abutments. Minor gravel bars and debris are noted. Hydraulic adequacy is noted as appearing adequate but narrow. (Continued, p. 33) 


\section{Bridge Hydrologic Data}

Is there hydrologic data available? $\underline{\mathbf{N}}$ if No, type ctrl-n $h \quad$ VTAOT Drainage area $\left(m i^{2}\right)$ : -

Terrain character:

Stream character \& type: -

Streambed material:

Discharge Data (cfs):

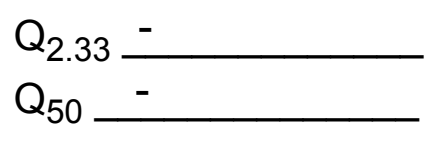

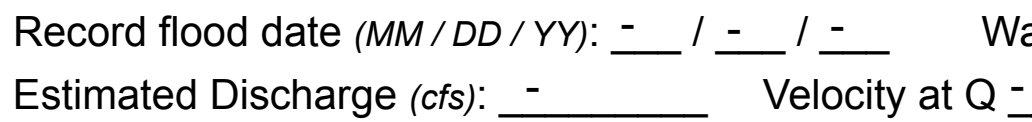

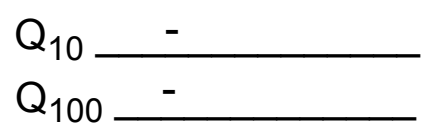

$\mathrm{Q}_{25}$

Water surface elevation $(f t):-$ $(\mathrm{ft} / \mathrm{s}):$

Ice conditions (Heavy, Moderate, Light) : -

Debris (Heavy, Moderate, Light):

The stage increases to maximum highwater elevation (Rapidly, Not rapidly):

The stream response is (Flashy, Not flashy):

Describe any significant site conditions upstream or downstream that may influence the stream's stage: -

Watershed storage area (in percent):

The watershed storage area is: - (1-mainly at the headwaters; 2- uniformly distributed; 3-immediatly upstream oi the site)

Water Surface Elevation Estimates for Existing Structure:

\begin{tabular}{|l|l|l|l|l|l|}
\hline Peak discharge frequency & $Q_{2.33}$ & $Q_{10}$ & $Q_{25}$ & $Q_{50}$ & $Q_{100}$ \\
Water surface elevation (ft)) & - & - & - & - & - \\
Velocity (ft/sec) & - & - & - & - & - \\
\hline
\end{tabular}

Long term stream bed changes: -

Is the roadway overtopped below the $Q_{100}$ ? (Yes, No, Unknown):

Frequency: -

Relief Elevation (ft):

Discharge over roadway at $Q_{100}\left(f^{3} / \mathrm{sec}\right)$ :

Are there other structures nearby? (Yes, No, Unknown): -

Upstream distance (miles):

Town: If No or Unknown, type ctrl-n os

Highway No. : Structure No. : Year Built:

Clear span (ft): Clear Height $(f t)$ : Full Waterway $\left(f^{2}\right)$ : 
Downstream distance (miles): Town: Year Built:

Highway No. : Structure No. : Structure Type:

Clear span (ft): Clear Height (ft): Full Waterway $\left(f^{2}\right)$ :

Comments:

A letter dated 8/17/89 from VTAOT to the town of Somerset notes that the abutments are in poor condition. The streambed at the US half of both abutments is approximately $1 \mathrm{ft}$ below the bottom of the abutment, and in some areas, undermining goes in under the abutment as much as $4 \mathrm{ft}$. The recommendation was to create a concrete subfooting and add riprap for protection. This work was noted as completed on 9/26/90.

\section{USGS Watershed Data}

Watershed Hydrographic Data

Drainage area $(D A) \underline{16.96} \mathrm{mi}^{2}$

Watershed storage (ST) $\quad \mathbf{2 . 2 9}$

Bridge site elevation 1872

Main channel length 8.017 $10 \%$ channel length elevation $\underline{2008}$

Main channel slope (S) 58.58 $\mathrm{ft} / \mathrm{mi}$ $\%$ $\mathrm{mi}$

Lake/pond/swamp area 0.388 $\mathrm{mi}^{2}$

Headwater elevation 3331 $\mathrm{ft}$ $\mathrm{ft} \quad 85 \%$ channel length elevation $\mathrm{ft}$

Watershed Precipitation Data

Average site precipitation in Average headwater precipitation in

Maximum 2yr-24hr precipitation event $(124,2)$ in

Average seasonal snowfall (Sn) $\mathrm{ft}$ 


\section{Bridge Plan Data}

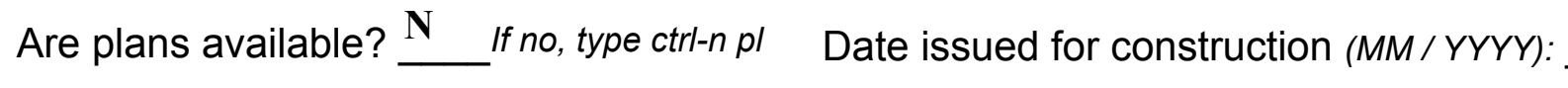

Project Number

Minimum channel bed elevation:

Low superstructure elevation: USLAB DSLAB USRAB DSRAB Benchmark location description:

NO BENCHMARK INFORMATION

Reference Point (MSL, Arbitrary, Other): Datum (NAD27, NAD83, Other):

Foundation Type: 4

If 1 : Footing Thickness

If 2: Pile Type:

If 3: Footing bottom elevation:

Is boring information available? $\mathbf{N}$

Foundation Material Type: $\mathbf{3}$

(1-Spreadfooting; 2-Pile; 3- Gravity; 4-Unknown)

Footing bottom elevation: -

Briefly describe material at foundation bottom elevation or around piles:

NO FOUNDATION MATERIAL INFORMATION 


\section{Cross-sectional Data}

Is cross-sectional data available? $\underline{\mathbf{Y}}$

If no, type ctrl-n xs

Source (FEMA, VTAOT, Other)? VTAOT

This cross section is the upstream face. The low chord elevations are from the survey log done Comments: for this report on 8/7/96. The low chord to bed length data come from the sketch attached to a bridge inspection report dated 9/10/93.

\begin{tabular}{|l|l|l|l|l|l|l|l|l|l|l|l|}
\hline Station & $\mathbf{0}$ & $\mathbf{5}$ & $\mathbf{1 1}$ & $\mathbf{2 0}$ & $\mathbf{3 0}$ & $\mathbf{3 5}$ & - & - & - & - & - \\
\hline Feature & LAB & - & - & - & - & RAB & - & - & - & - & - \\
\hline $\begin{array}{l}\text { Low chord } \\
\text { elevation }\end{array}$ & $\mathbf{5 0 8 . 3}$ & $\mathbf{5 0 8 . 3}$ & $\mathbf{5 0 8 . 2}$ & $\mathbf{5 0 8 . 1}$ & $\mathbf{5 0 8 . 0}$ & $\mathbf{5 0 8 . 0}$ & - & - & - & - & - \\
\hline $\begin{array}{l}\text { Bed } \\
\text { elevation }\end{array}$ & $\mathbf{4 9 7 . 6}$ & $\mathbf{4 9 6 . 1}$ & $\mathbf{4 9 6 . 2}$ & $\mathbf{4 9 7 . 2}$ & $\mathbf{4 9 6 . 5}$ & $\mathbf{4 9 7 . 7}$ & - & - & - & - & - \\
\hline $\begin{array}{l}\text { Low chord } \\
\text { to bed }\end{array}$ & $\mathbf{1 0 . 7}$ & $\mathbf{1 2 . 2}$ & $\mathbf{1 2 . 0}$ & $\mathbf{1 0 . 9}$ & $\mathbf{1 1 . 5}$ & $\mathbf{1 0 . 3}$ & - & - & - & - & - \\
\hline Station & - & - & - & - & - & - & - & - & - & - & - \\
\hline Feature & - & - & - & - & - & - & - & - & - & - & - \\
\hline $\begin{array}{l}\text { Low chord } \\
\text { elevation }\end{array}$ & - & - & - & - & - & - & - & - & - & - & - \\
\hline $\begin{array}{l}\text { Bed } \\
\text { elevation }\end{array}$ & - & - & - & - & - & - & - & - & - & - & - \\
\hline $\begin{array}{l}\text { Low chord } \\
\text { to bed }\end{array}$ & - & - & - & - & - & - & - & - & - & - & - \\
\hline
\end{tabular}

Source (FEMA, VTAOT, Other)?

Comments:

\begin{tabular}{|l|l|l|l|l|l|l|l|l|l|l|l|}
\hline Station & - & - & - & - & - & - & - & - & - & - & - \\
\hline Feature & - & - & - & - & - & - & - & - & - & - & - \\
\hline $\begin{array}{l}\text { Low chord } \\
\text { elevation }\end{array}$ & - & - & - & - & - & - & - & - & - & - & - \\
\hline $\begin{array}{l}\text { Bed } \\
\text { elevation }\end{array}$ & - & - & - & - & - & - & - & - & - & - & - \\
\hline $\begin{array}{l}\text { Low chord } \\
\text { to bed }\end{array}$ & - & - & - & - & - & - & - & - & - & - & - \\
\hline Station & - & - & - & - & - & - & - & - & - & - & - \\
\hline Feature & - & - & - & - & - & - & - & - & - & - & - \\
\hline $\begin{array}{l}\text { Low chord } \\
\text { elevation }\end{array}$ & - & - & - & - & - & - & - & - & - & - & - \\
\hline $\begin{array}{l}\text { Bed } \\
\text { elevation }\end{array}$ & - & - & - & - & - & - & - & - & - & - & - \\
\hline $\begin{array}{l}\text { Low chord } \\
\text { to bed }\end{array}$ & - & - & - & - & - & - & - & - & - & - & - \\
\hline
\end{tabular}




\section{APPENDIX E: \\ LEVEL I DATA FORM}


U. S. Geological Survey

Bridge Field Data Collection and Processing Form

Qa/Qc Check by: EW Date: $\underline{\mathbf{1 0} / \mathbf{1 0} / 96}$

\section{Structure Number SOMMTH00010002} Computerized by: $\underline{\mathbf{E W}}$ Date: 10/10/96

Reviewd by: $\quad \mathbf{R B}$ Date: $\underline{\mathbf{3} / \mathbf{1 3} / \mathbf{9 8}}$

\section{A. General Location Descriptive}

1. Data collected by (First Initial, Full last name) R. BURNS

2. Highway District Number 01

County WINDHAM (025)

Waterway (l - 6) RAKE BRANCH DEERFIELD R.

Route Number C3001

3. Descriptive comments:

The bridge is located 4.9 miles from the junction with VT 9. It has a concrete filled steel grid deck with an asphalt overlay. There are concrete filled bags along the bottom of the abutments.
Mile marker 000000

Road Name -

Hydrologic Unit Code: $\mathbf{0 1 0 8 0 2 0 3}$
Town SOMERSET (65762)

\section{B. Bridge Deck Observations}
4. Surface cover... LBUS 6
RBUS 6
LBDS 6
RBDS 6
Overall 6

(2b us,ds,lb,rb: 1- Urban; 2- Suburban; 3- Row crops; 4- Pasture; 5- Shrub- and brushland; 6- Forest; 7- Wetland)
5. Ambient water surface... US $\underline{2}$
UB 2
DS $\underline{2}$
(1- pool; 2- riffle)

6. Bridge structure type 1 (1- single span; 2- multiple span; 3- single arch; 4- multiple arch; 5-cylindrical culvert; 6- box culvert; or 7- other)
7. Bridge length 45
(feet)
Span length $\mathbf{3 8}$
(feet)
Bridge width 14 (feet)

\section{Road approach to bridge:}
8. LB 2 RB $\underline{\mathbf{0}}$
( 0 even, 1- lower, 2- higher)
9. LB 2 RB 2
(1-Paved, 2- Not paved)

10. Embankment slope (run / rise in feet / foot):
US left
2.4:1
US right
2.3:1

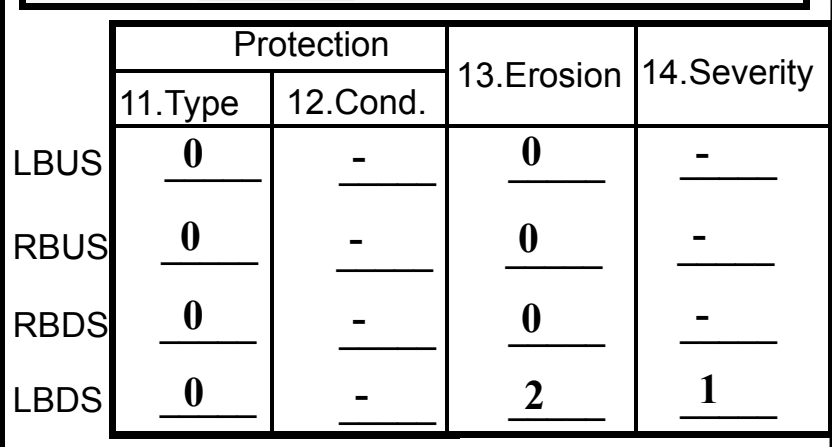

Bank protection types: 0- none; 1- $<12$ inches;

2- < 36 inches; 3- < 48 inches;

4- < 60 inches; 5- wall / artificial levee

Bank protection conditions: 1- good; 2- slumped;

3- eroded; 4- failed

Erosion: 0 - none; 1- channel erosion; 2-

road wash; 3- both; 4- other

Erosion Severity: 0 - none; 1- slight; 2- moderate; 3- severe

\section{Channel approach to bridge (BF):}

15. Angle of approach: $\mathbf{0}$

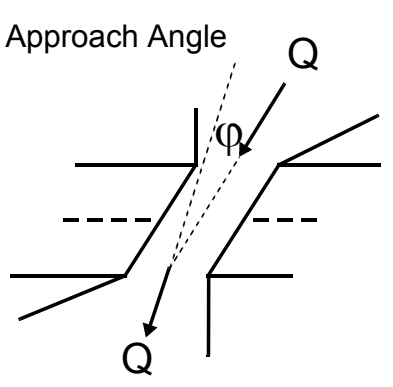

17. Channel impact zone 1 :

Where? $(L B, R B)$

Range? feet -

Channel impact zone 2:

Where? $(L B, R B)$

Range? - $\quad$ feet -

(US, UB, DS) to feet Impact Severity: 0- none to very slight; 1-Slight; 2- Moderate; 3- Severe

16. Bridge skew: $\mathbf{0}$ Bridge Skew Angle

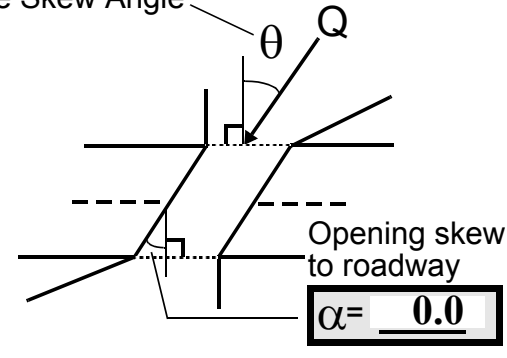

Exist? $\mathbf{N}(Y$ or $N)$

Severity -

(US, UB, DS) to -

Exist? $\mathbf{N}(Y$ or $N)$

Severity - 
18. Bridge Type: 4

1a- Vertical abutments with wingwalls

$1 \mathrm{~b}$ - Vertical abutments without wingwalls

2- Vertical abutments and wingwalls, sloping embankment Wingwalls parallel to abut. face

3- Spill through abutments

4- Sloping embankment, vertical wingwalls and abutments

Wingwall angle less than $90^{\circ}$.

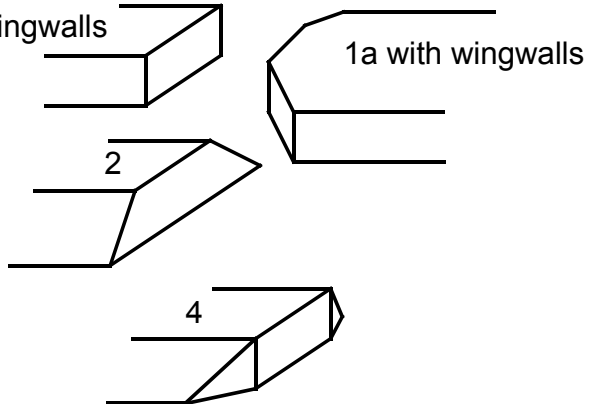

19. Bridge Deck Comments (surface cover variations, measured bridge and span lengths, bridge type variations, approach overflow width, etc.)

\#4: On the RBDS there is a break in the forest at approximately 50 feet downstream where there are shrubs and brush.

\#7: Values are from the VTAOT database. Measured bridge length is 45 feet; width is 14.3 feet; span is 35.5 feet between the insides of the abutments and span is 39.5 feet between the insides of the backwalls.

\#9: The road approaches are gravel and the bridge deck is paved.

\#11: There are two culverts under the road on the right bank. On the DSRB a gully at the bottom of the road embankment runs into the stream at the downstream end of the DSRWW.

\#15: This is a very straight reach of the channel.

\#18: Wingwalls slope down below low chord, but not all the way down to the stream bed.

\section{Upstream Channel Assessment}

\begin{tabular}{|c|c|c|c|c|c|c|c|c|c|c|}
\hline \multicolumn{5}{|c|}{ 21. Bank height (BF) 22. Bank angle (BF) } & \multicolumn{2}{|c|}{ 26. \% Veg. cover (BF) } & \multicolumn{2}{|c|}{ 27. Bank material (BF) } & \multicolumn{2}{|c|}{ 28. Bank erosion (BF } \\
\hline 20. SRD & LB & RB & LB & RB & LB & RB & LB & RB & LB & RB \\
\hline 38.0 & 3.5 & & & 2.0 & 4 & 4 & 435 & 435 & $\mathbf{0}$ & $\mathbf{0}$ \\
\hline 23. Bank & & & 24. $C$ & nel width & 15.0 & 25. Th & weg dep & 60.0 & & 435 \\
\hline
\end{tabular}

\section{0}

30 .Bank protection type:

LB 0

RB 0

31. Bank protection condition: LB -

$\mathrm{RB}$ -

SRD - Section ref. dist. to US face \% Vegetation (Veg) cover: 1- 0 to 25\%; 2- 26 to $50 \%$; 3- 51 to $75 \%$; 4- 76 to $100 \%$

Bed and bank Material: 0- organics; 1- silt / clay, <1/16mm; 2- sand, 1/16 - 2mm; 3- gravel, 2 - 64mm;

4- cobble, 64 - 256mm; 5- boulder, > 256mm; 6- bedrock; 7-manmade

Bank Erosion: 0- not evident; 1- light fluvial; 2- moderate fluvial; 3- heavy fluvial / mass wasting

Bank protection types: 0- absent; 1- < 12 inches; 2- < 36 inches; 3- < 48 inches; 4- < 60 inches; 5- wall / artificial levee

Bank protection conditions: 1- good; 2- slumped; 3- eroded; 4- failed

32. Comments (bank material variation, minor inflows, protection extent, etc.):

There are natural stones along the banks.

The banks are shallow and low.

There is a wide strip of grass on the right bank before the tree line.

About 300 feet upstream, on the right bank, there is a swath of grass through the trees where the water is diverted to the culverts under the road, during high flows. 
33.Point/Side bar present? Y

$(Y$ or $N$. if $N$ type ctrl-n pb)34. Mid-bar distance: $\mathbf{2 0}$

35. Mid-bar width: 12

36. Point bar extent: $\mathbf{5 5}$ feet US (US, UB) to 10 feet $\underline{\mathbf{U S}}$ (US, UB, DS) positioned $\underline{\mathbf{0}}$ $\%$ LB to 30 $\%$ RB

37. Material: 435

38. Point or side bar comments (Circle Point or Side; Note additional bars, material variation, status, etc.):

This side bar is vegetated with grass.

39. Is a cut-bank present? $\mathbf{N}$ ( $Y$ or if $N$ type ctrl-n cb)

40. Where? - $\quad$ (LB or RB)

41. Mid-bank distance: -

42. Cut bank extent: -

feet -

(US, UB) to feet (US, UB, DS)

43. Bank damage: (1- eroded and/or creep; 2- slip failure; 3- block failure)

44. Cut bank comments (eg. additional cut banks, protection condition, etc.):

NO CUT BANKS

45. Is channel scour present? $\mathbf{N}$ (Y or if $N$ type ctrl-n cs)

47. Scour dimensions: Length Width Depth : 46. Mid-scour distance: -

48. Scour comments (eg. additional scour areas, local scouring process, etc.):

NO CHANNEL SCOUR

49. Are there major confluences? $\mathbf{N}$

51. Confluence 1: Distance Confluence 2: Distance 52. Enters on Enters on 54. Confluence comments (eg. confluence name):

NO MAJOR CONFLUENCES
50. How many? -

53. Type(1- perennial; 2- ephemeral)

Type (1-perennial; 2- ephemeral) ( $L B$ or $R B)$

\section{Under Bridge Channel Assessment}

55. Channel restraint (BF)? LB 2

\begin{tabular}{|ccccc}
\hline \multicolumn{2}{|c}{ 56. Height (BF) } & \multicolumn{3}{c}{57 Angle (BF) } \\
LB & RB & LB & RB \\
$\mathbf{4 3 . 0}$ & & & $\mathbf{1 . 0}$ & \\
\hline
\end{tabular}

58. Bank width (BF) (1- natural bank; 2- abutment; 3- artificial levee)

Bed and bank Material: 0- organics; 1- silt / clay, < 1/16mm; 2- sand, 1/16 - 2mm; 3- gravel, 2 - 64mm; 4- cobble, 64 - 256mm;

5- boulder, > 256mm; 6- bedrock; 7- manmade
Bank Erosion: 0- not evident; 1- light fluvial; 2- moderate fluvial; 3- heavy fluvial / mass wasting

61. Material (BF) 62. Erosion (BF)

LB RB LB RB

$\underline{2} \quad \underline{7} \quad \underline{-}$

59. Channel width - 60. Thalweg depth $\lcm{\mathbf{9 0 . 0}}$

63. Bed Material -

64. Comments (bank material variation, minor inflows, protection extent, etc.):

435

At the upstream bridge face, there is a riffle caused by boulders in the center of the channel. At the present water level, flow is directed towards both abutments from this riffle. 
65. Debris and Ice Is there debris accumulation?

67. Debris Potential (1- Low; 2- Moderate; 3- High)

69. Is there evidence of ice build-up? 1 (Y or N)

70. Debris and Ice Comments:
(Yor $N)$ 66. Where? $\mathbf{N}$

68. Capture Efficiency 2

(1- Upstream; 2- At bridge; 3-Both)

Ice Blockage Potential $\mathbf{N}$
(1- Low; 2- Moderate; 3- High)

(1-Low; 2- Moderate; 3- High) 1

\begin{tabular}{|l|c|c|c|c|c|c|c|c|}
\hline Abutments & $\begin{array}{c}\text { 71. Attack } \\
\angle \text { (BF) }\end{array}$ & $\begin{array}{c}\text { 72. Slope } \angle \\
\text { (Qmax) }\end{array}$ & $\begin{array}{c}\text { 73. Toe } \\
\text { loc. (BF) }\end{array}$ & $\begin{array}{c}\text { 74. Scour } \\
\text { Condition }\end{array}$ & $\begin{array}{c}75 . \text { Scour } \\
\text { depth }\end{array}$ & $\begin{array}{c}\text { 76. Exposure } \\
\text { depth }\end{array}$ & 77. Material & 78. Length \\
\hline LABUT & & $\mathbf{0}$ & $\mathbf{9 0}$ & $\mathbf{2}$ & $\mathbf{0}$ & - & - & $\mathbf{9 0 . 0}$ \\
\hline RABUT & $\mathbf{1}$ & $\mathbf{5}$ & $\mathbf{9 0}$ & & & $\mathbf{2}$ & $\mathbf{0}$ & $\mathbf{3 5 . 5}$ \\
\hline
\end{tabular}

Pushed: $L B$ or RB

Toe Location (Loc.): 0- even, 1- set back, 2- protrudes

Scour cond.: 0- not evident; 1- evident (comment); 2- footing exposed; 3-undermined footing; 4- piling exposed; 5- settled; 6- failed

Materials: 1- Concrete; 2- Stone masonry or drywall; 3- steel or metal; 4- wood

79. Abutment comments (eg. undermined penetration, unusual scour processes, debris, etc.):

$-$

1

The abutments are protected with bags of concrete along the upstream three-quarters of the abutment.

80. Wingwalls:

Exist? Material? Scour Scour Exposure Angle? Length?

USLWW: Condition? depth? depth?

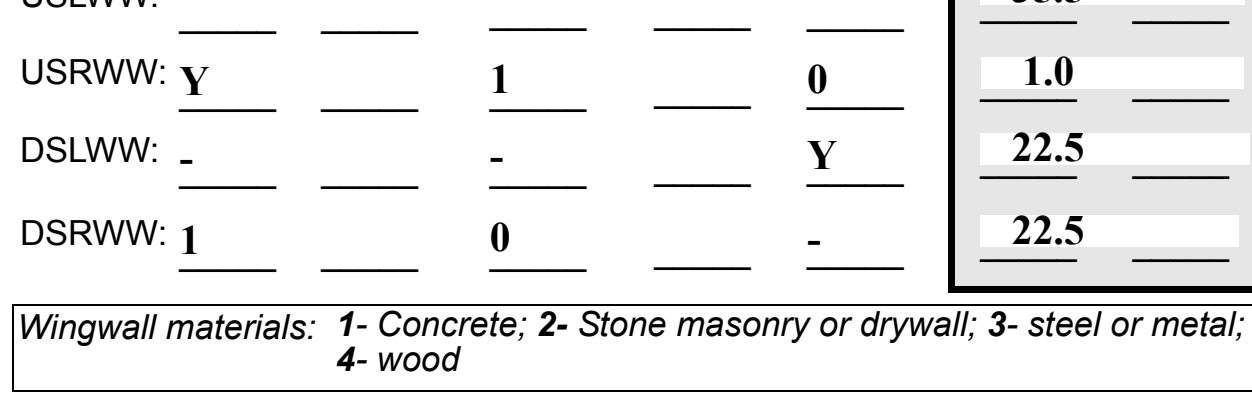

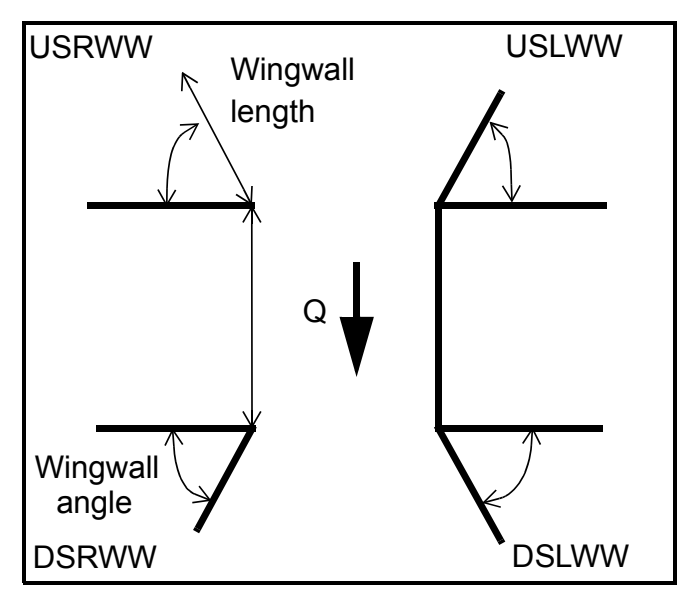

82. Bank / Bridge Protection:

\begin{tabular}{|l|l|l|l|l|l|l|l|l|}
\hline Location & USLWW & USRWW & LABUT & RABUT & LB & RB & DSLWW & DSRWW \\
\hline Type & - & $\mathbf{0}$ & $\mathbf{Y}$ & - & $\mathbf{1}$ & $\mathbf{1}$ & - & - \\
\hline Condition & $\mathbf{Y}$ & - & $\mathbf{1}$ & - & $\mathbf{1}$ & $\mathbf{2}$ & - & - \\
\hline Extent & $\mathbf{1}$ & - & $\mathbf{0}$ & $\mathbf{2}$ & $\mathbf{2}$ & $\mathbf{0}$ & $\mathbf{0}$ & - \\
\hline
\end{tabular}

Bank / Bridge protection types: 0- absent; 1- < 12 inches; 2- < 36 inches; 3- < 48 inches; 4- < 60 inches; 
83. Wingwall and protection comments (eg. undermined penetration, unusual scour processes, etc.):

-
-
-
-
-
2
1
1
2
1
1

\section{Piers:}

84. Are there piers? Th (Y or if $N$ type ctrl-n pr)

\begin{tabular}{|l|l|l|l|l|l|l|l|}
\hline \multirow{2}{*}{$\begin{array}{l}85 . \\
\text { Pier no. }\end{array}$} & \multicolumn{3}{|c|}{ width (w) feet } & \multicolumn{3}{c|}{ elevation (e) feet } \\
\cline { 2 - 8 } & w1 & w2 & w3 & e@w1 & e@w2 & e@w3 \\
\hline Pier 1 & & & & $\mathbf{4 5 . 0}$ & $\mathbf{1 0 . 0}$ & $\mathbf{4 5 . 0}$ \\
\hline Pier 2 & & & & $\mathbf{1 0 . 0}$ & $\mathbf{4 5 . 0}$ & $\mathbf{1 0 . 0}$ \\
\hline Pier 3 & & & - & $\mathbf{4 5 . 0}$ & $\mathbf{1 0 . 0}$ & - \\
\hline Pier 4 & - & - & - & - & - & - \\
Nyyyy
\end{tabular}

\begin{tabular}{|l|l|l|l|l|}
\hline Level 1 Pier Descr. & \multicolumn{1}{|c|}{1} & \multicolumn{1}{|c|}{2} & 3 & \multicolumn{1}{|l|}{} \\
\hline 86. Location (BF) & ere are & walls. & - & - \\
\hline 87. Type & bags & & - & - \\
\hline 88. Material & of & & - & - \\
\hline 89. Shape & con- & & - & - \\
\hline 90. Inclined? & crete & & - & - \\
\hline 91. Attack $\angle$ (BF) & in & & - & - \\
\hline 92. Pushed & front & & - & - \\
\hline 93. Length (feet) & - & - & - & - \\
\hline 94. \# of piles & of & & - & - \\
\hline 95. Cross-members & the & & - & - \\
\hline 96. Scour Condition & upst & & - & - \\
\hline 97. Scour depth & ream & & - & - \\
\hline 98. Exposure depth & wing & N & - & - \\
\hline
\end{tabular}

LFP, LTB, LB, MCL, MCM, MCR, RB, RTB, RFP

1- Solid pier, 2- column, 3- bent

1-Wood; 2- concrete; 3- metal; 4- stone

1- Round; 2- Square; 3- Pointed

Y-yes; $N-$ no

$L B$ or $R B$

0- none; 1- laterals; 2- diagonals; 3- both

0- not evident; 1- evident (comment);

2- footing exposed; 3- piling exposed;

4- undermined footing; 5- settled; 6-failed 
99. Pier comments (eg. undermined penetration, protection and protection extent, unusual scour processes, etc.):

-
-
-
-
-
-
-
-
-
-

100.

\section{E. Downstream Channel Assessment}

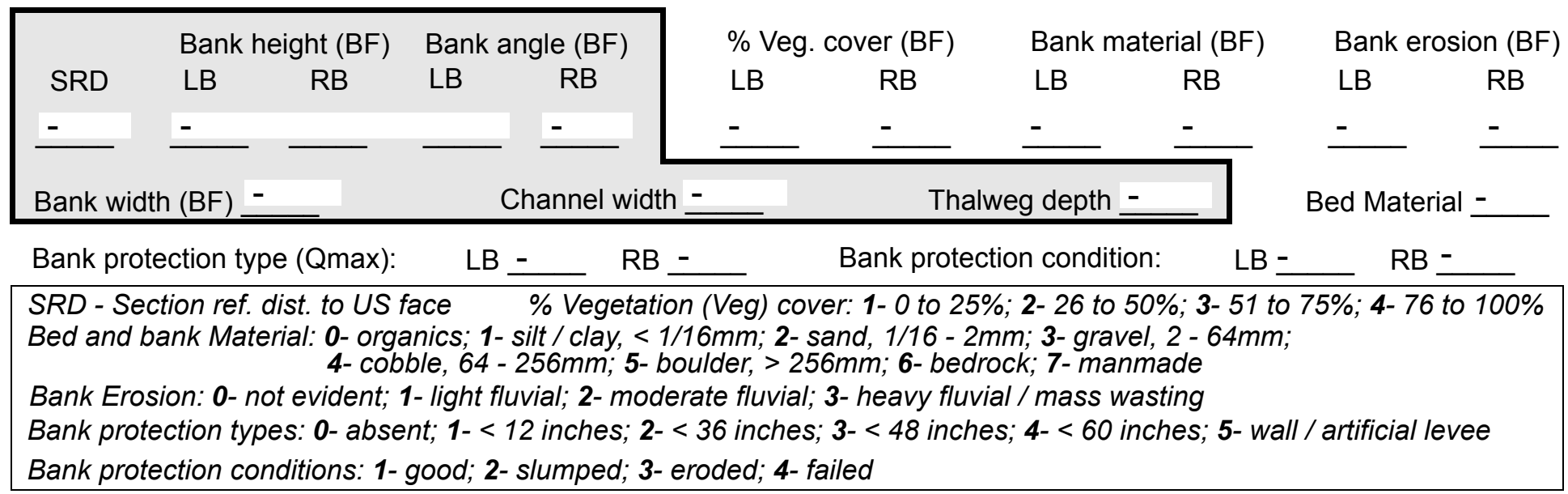

Comments (eg. bank material variation, minor inflows, protection extent, etc.):

$$
-
$$

$-$

$-$

\section{NO PIERS}

101. Is a drop structure present? 45 ( $Y$ or $N$, if $N$ type ctrl-n ds) 102. Distance: - feet

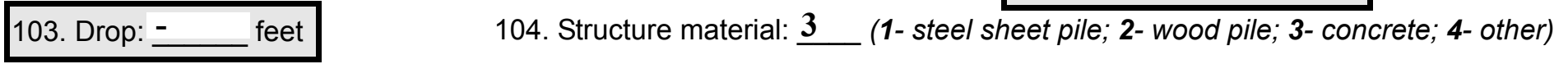
105. Drop structure comments (eg. downstream scour depth): 453 0 1 453 
106. Point/Side bar present? (Y or $N$. if $N$ type ctrl-n pb)Mid-bar distance: Mid-bar width: Ther

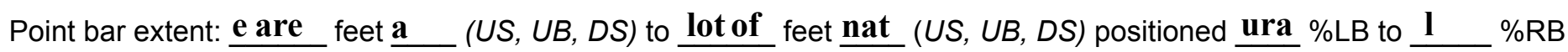
Material: sto

Point or side bar comments (Circle Point or Side; note additional bars, material variation, status, etc.):

nes on the bank.

Is a cut-bank present?

Cut bank extent: feet (Y or if $N$ type ctrl-n cb) Where? (LB or $R B)$ feet (US, UB, DS)

Bank damage: (US, UB, DS) to (1- eroded and/or creep; 2- slip failure; 3- block failure)

Cut bank comments (eg. additional cut banks, protection condition, etc.):

N

Is channel scour present? ( $Y$ or if $N$ type ctrl-n cs)

Mid-scour distance: $\mathbf{N O}$ Scour dimensions: Length DRO Width $\mathbf{P}$ Depth: STR Positioned UC \%LB to $\underline{\text { TU }} \%$ RB Scour comments (eg. additional scour areas, local scouring process, etc.):

RE

Are there major confluences? (Y or if $N$ type ctrl-n $m c)$

Confluence 1: Distance $\underline{\mathbf{Y}}$

Confluence 2: Distance $\underline{\mathbf{0}}$ Enters on 10 (LB or RB) Enters on $\underline{\mathbf{D S}}$ (LB or RB)

Confluence comments (eg. confluence name):

DS

80

\section{F. Geomorphic Channel Assessment}

107. Stage of reach evolution
1- Constructed

2- Stable

3- Aggraded

4- Degraded

5- Laterally unstable

6- Vertically and laterally unstable 
108. Evolution comments (Channel evolution not considering bridge effects; See HEC-20, Figure 1 for geomorphic descriptors):

453

$-$

Y

RB

80

70

DS

90

DS

1 


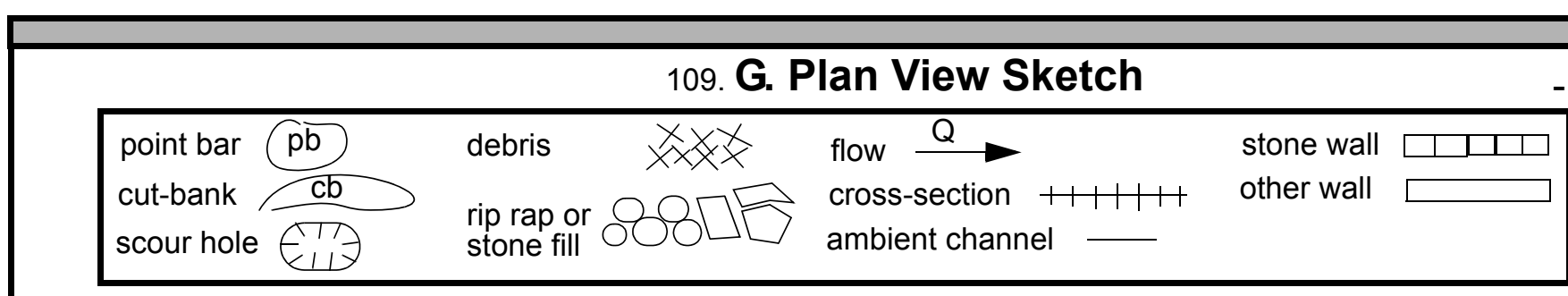

cut-bank $\mathrm{cb}$

scour hole rip rap or
stone fill stone fill cross-section $+1+1+1$ ambient channe other wall 
APPENDIX F:

SCOUR COMPUTATIONS 
SCOUR COMPUTATIONS

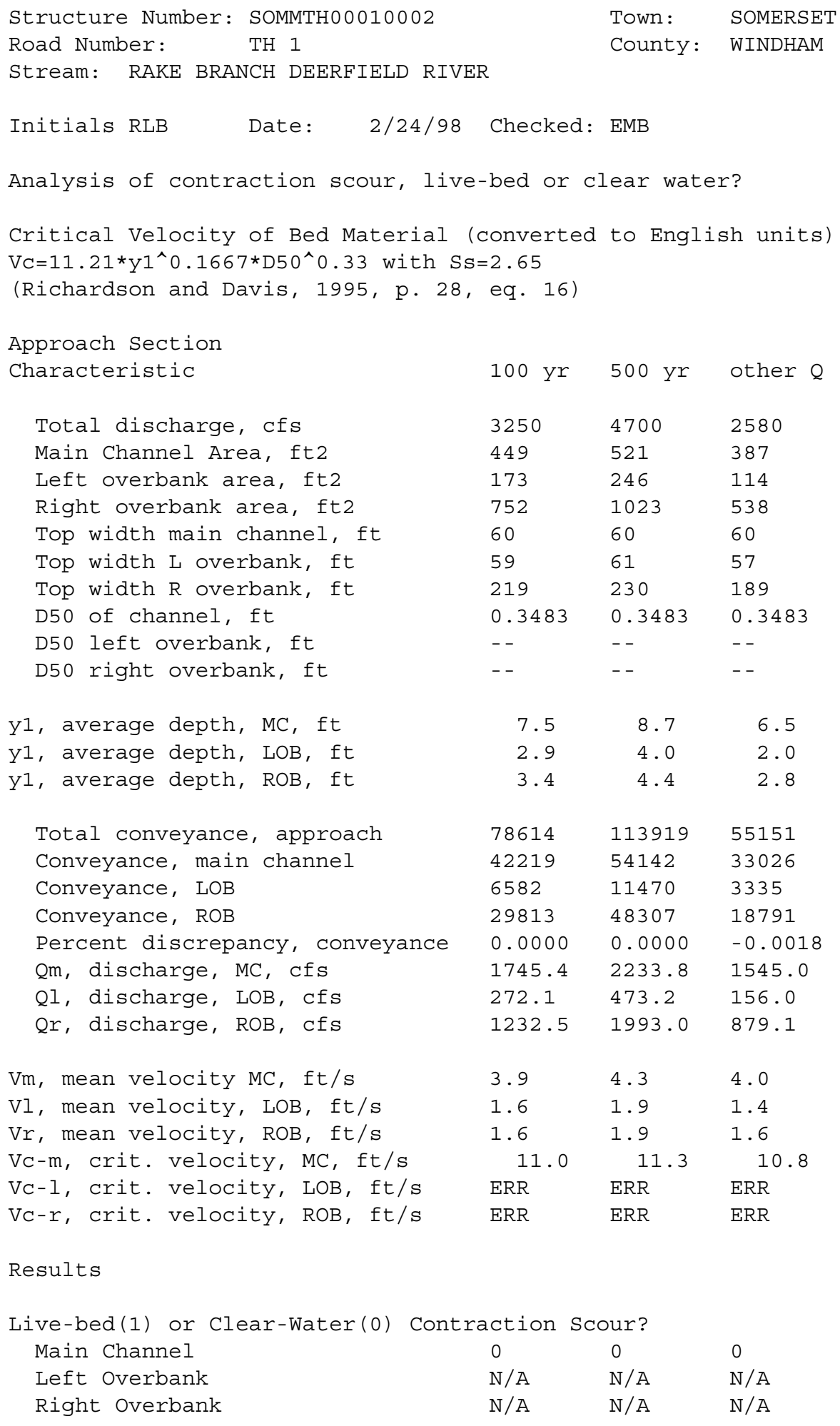


Clear water Contraction Scour in MAIN CHANNEL

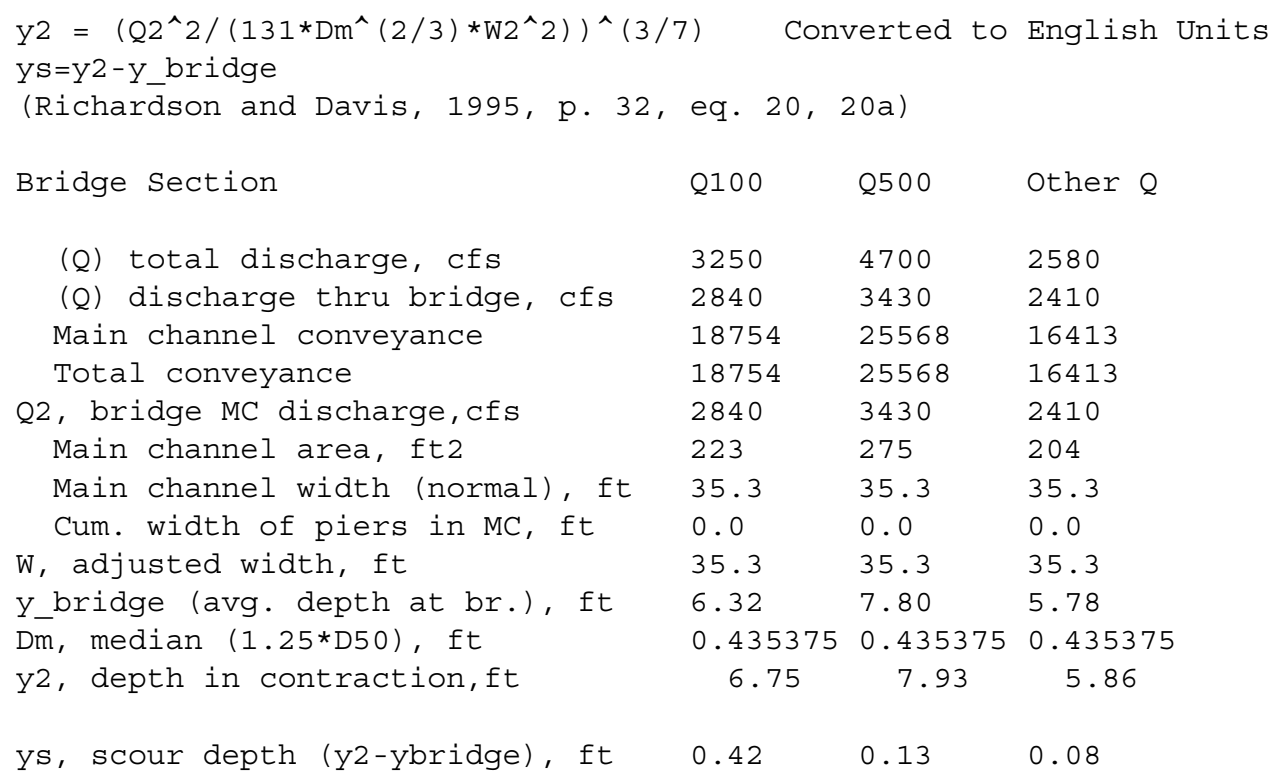

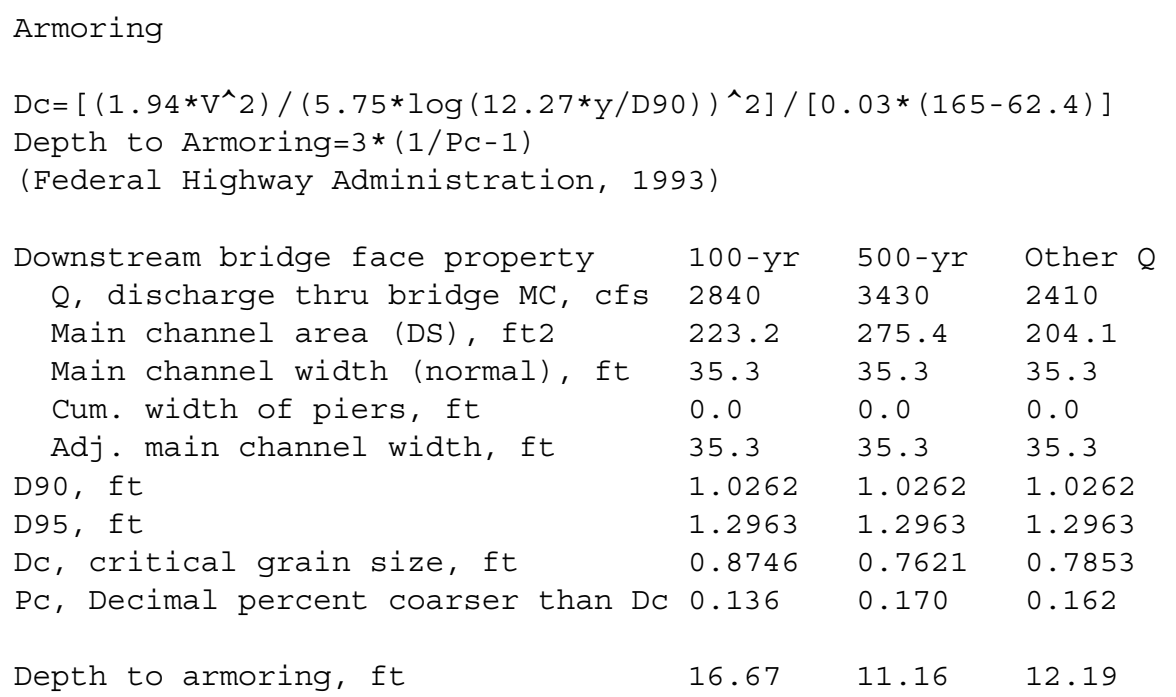




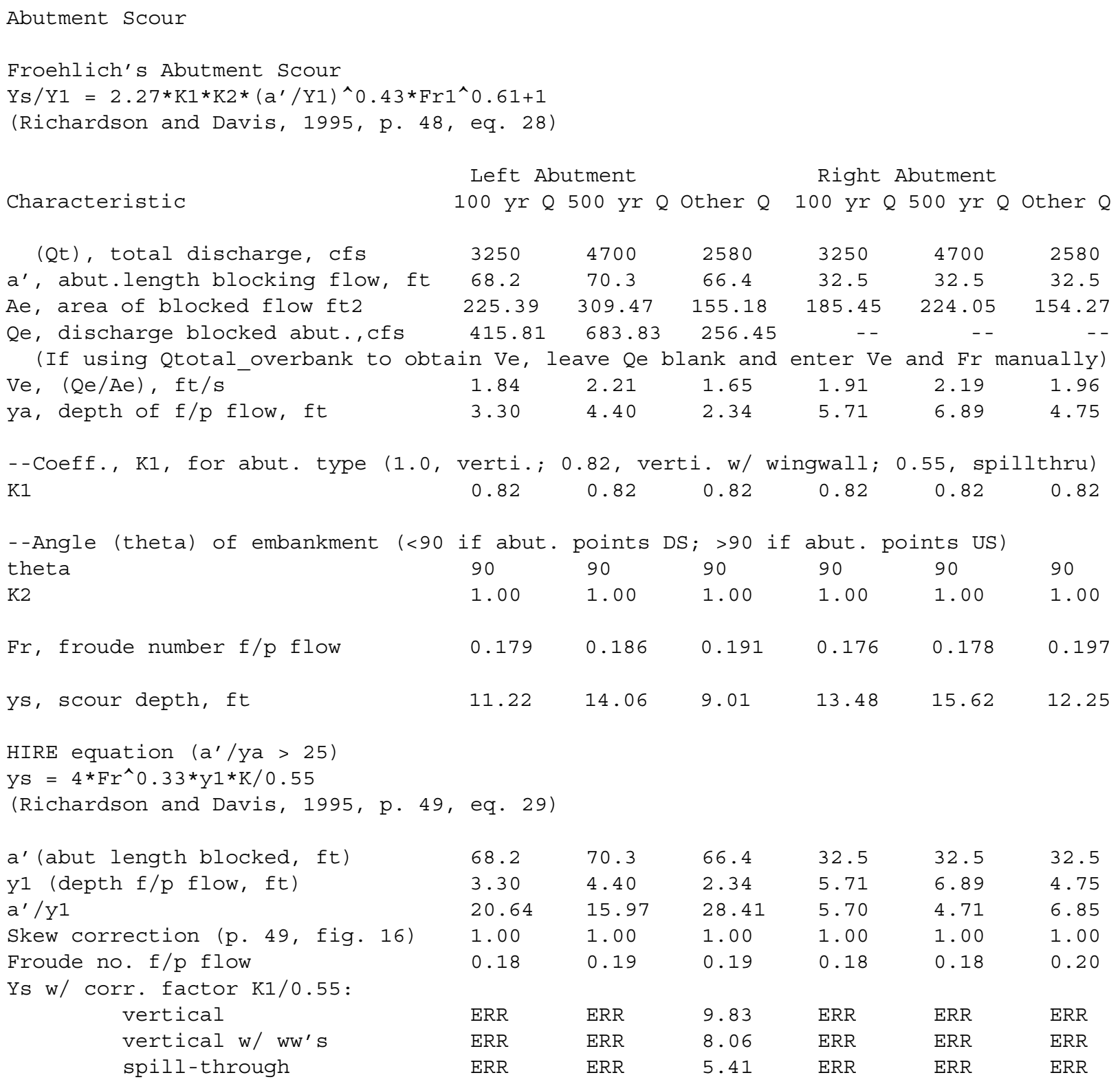




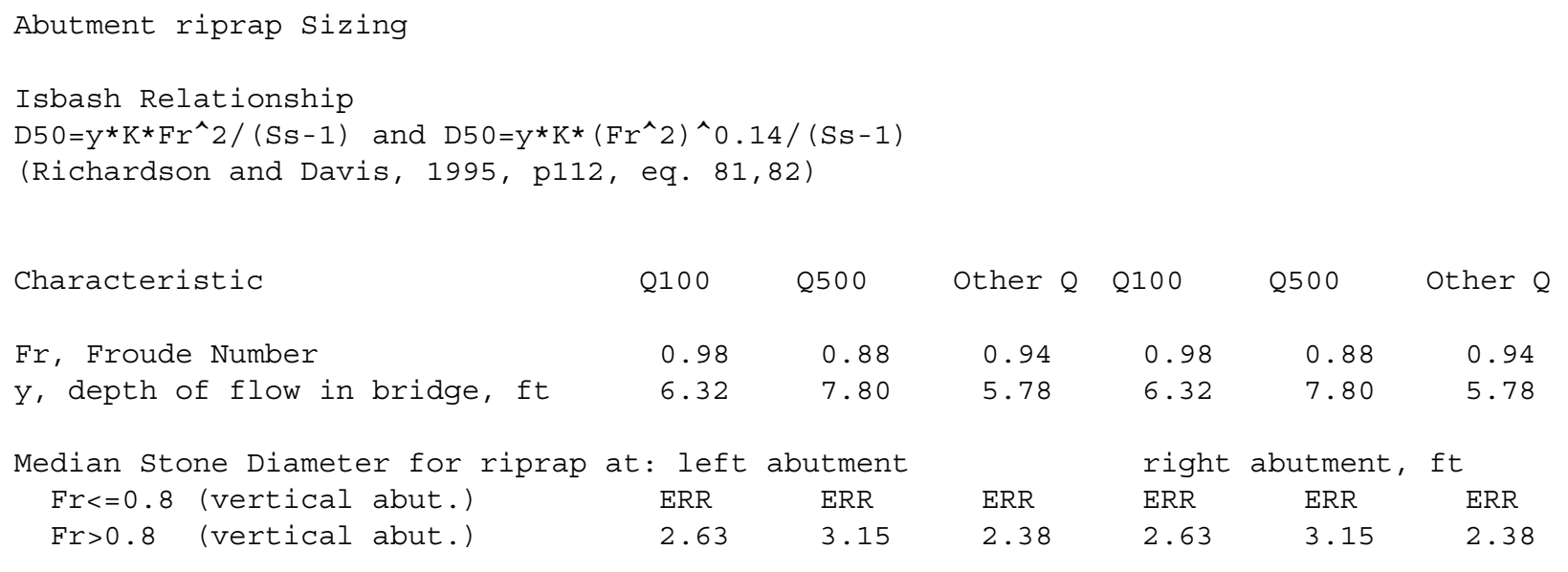

